\title{
Cyclic AMP and Polyamines Overcome Inhibition by Myelin- Associated Glycoprotein through eIF5A-Mediated Increases in p35 Expression and Activation of Cdk5
}

\author{
Huifang He, Kangwen Deng, Mustafa M. Siddiq, Aung Pyie, Wilfredo Mellado, ${ }^{\circledR S}$ Sari S. Hannila, and Marie T. Filbin ${ }^{\dagger}$ \\ Department of Biological Sciences, Hunter College, City University of New York, New York, New York 10065
}

Inhibitory molecules associated with CNS myelin, such as myelin-associated glycoprotein (MAG), represent major obstacles to axonal regeneration following CNS injury. Our laboratory has shown that elevating levels of intracellular cAMP, via application of the nonhydrolyzable analog dibutyryl cAMP (dbcAMP), can block the inhibitory effects of MAG and myelin. We have also shown that elevation of cAMP results in upregulation of arginase I and increased polyamine synthesis. Treatment with putrescine or spermidine blocks myelinmediated inhibition of neurite outgrowth, but the mechanism underlying this effect has not yet been elucidated. Here we show that cyclin-dependent kinase 5 (Cdk5) is required for dbcAMP and putrescine to overcome MAG-mediated inhibition. The ability of dbcAMP and putrescine to overcome inhibition by MAG is abolished in the presence of roscovitine, a Cdk inhibitor that has greater selectivity for Cdk5, and expression of dominant negative Cdk5 abolishes the ability of dbcAMP or putrescine to enhance neurite outgrowth in the presence of MAG. Importantly, dbcAMP and putrescine increase expression of p35, the neuron-specific activator of Cdk5, and rat DRG neurons transduced with HSV overexpressing p35 can overcome inhibition by MAG. The upregulation of p35 by putrescine is also reflected in increased localization of p35 to neurites and growth cones. Last, we show that putrescine upregulates p35 expression by serving as a substrate for hypusine modification of eIF5A, and that this hypusination is necessary for putrescine's ability to overcome inhibition by MAG. Our findings reveal a previously unknown mechanism by which polyamines may encourage regeneration after CNS injury.

Key words: Cdk5; eIF5A; MAG; neurite; p35; putrescine

\section{Significance Statement}

This study describes a novel mechanism for the activation of Cdk 5 in neurons and a new role for Cdk 5 in promoting axonal growth in the presence of myelin-associated inhibitors. We show that administration of the polyamine putrescine leads to hypusination of the translation initiation factor eIF5A, increased translation of $\mathrm{p} 35$, and activation of Cdk 5 in cultured cerebellar neurons, and that each of these events is required for putrescine's ability to overcome inhibition by myelin-associated glycoprotein. These findings have implications for the development of new treatments for spinal cord and traumatic brain injury and provide new insight into the functions of eIF5A and Cdk5 in the nervous system.

\section{Introduction}

Following injury to the adult CNS, axonal regeneration is inhibited by CNS myelin proteins such as myelin-associated glycopro-

\footnotetext{
Received Nov. 6, 2015; revised Jan. 28, 2016; accepted Feb. 5, 2016.

Author contributions: M.T.F. designed research;H.H., K.D., M.M.S., A.P., and W.M. performed research; H.H., K.D., and S.S.H. analyzed data; H.H. and S.S.H. wrote the paper.

This work was supported by the Specialized Neuroscience Research Program (NINDS Grants 3U54NS041073 and R01NS037060) and an infrastructure grant from the Research Centers in Minority Institutions Program (NCRR Grant RR003037) at Hunter College. We thank Dr. Solomon H. Snyder of the Johns Hopkins University School of Medicine (Baltimore, MD) for providing the GC-7 compound, and Dr. Rachael Neve, Director of the Viral Gene Transfer core at the Massachusetts Institute of Technology (Boston, MA), for providing the 35 and dominant negative Cdk5 HSV. We also thank Drs. Marco Domeniconi, Nagarathnamma Chaudhry, and Christine R. Cain for their input on this manuscript. This work is dedicated to the memory of Marie T. Filbin.

${ }^{\dagger}$ Deceased January 15, 2014.

The authors declare no competing financial interests.
}

tein (MAG), Nogo, and oligodendrocyte myelin glycoprotein (Filbin, 2003). Studies from our laboratory and others have established that elevation of intracellular cAMP can reverse inhibition by CNS myelin and promote regeneration of spinal axons in

Correspondence should be addressed to Dr. Sari S. Hannila, Department of Human Anatomy and Cell Science, University of Manitoba, 745 Bannatyne Avenue, Winnipeg, MB, Canada R3E 0J9. E-mail: sari.hannila@umanitoba.ca.

M. M. Siddiq's present address: Pharmacology and Systems Therapeutics, Icahn Medical Institute, Mount Sinai School of Medicine, 1425 Madison Avenue, New York, NY 10029.

W. Mellado's present address: Burke-Cornell Medical Research Institute, 785 Mamaroneck Avenue, White Plains, NY 10605.

S. S. Hannila's present address: Department of Human Anatomy and Cell Science, University of Manitoba, 745 Bannatyne Avenue, Winnipeg, MB, Canada R3E 0J9.

DOI:10.1523/JNEUROSCI.4012-15.2016

Copyright $\odot 2016$ the authors $\quad 0270-6474 / 16 / 363079-13 \$ 15.00 / 0$ 
vivo (Cai et al., 1999; Qiu et al., 2002). We have also demonstrated that arginase I expression and polyamine synthesis are required for the ability of cAMP to reverse myelin-mediated inhibition and that treatment with exogenous putrescine overcome inhibition by MAG in vitro (Cai et al. 2002). We subsequently showed that putrescine must be converted to spermidine to have this effect and, most importantly, that spermidine can promote regeneration of retinal ganglion cell axons following optic nerve injury (Deng et al., 2009). In this study, we report that the ability of putrescine to overcome inhibition by MAG and myelin arises from spermidine's function as substrate for the hypusine modification of elongation initiation factor 5A (eIF5A).

eIF5A is highly conserved in eukaryotes and is activated by a unique posttranslational modification known as hypusination, in which the 4-aminobutyl group of spermidine is transferred to the $\varepsilon$-amino group of Lys50 to generate deoxyhypusine, which is then hydroxylated to form hypusine (Park, 2006). Studies performed in yeast have provided evidence that eIF5A plays an important role in both the initiation and elongation phases of translation (Benne and Hershey, 1978, Saini et al., 2009, Gutierrez et al., 2013), but relatively little is known about its specific role in the nervous system and the function of the proteins that are translated in response to eIF5A activation. Importantly, however, one study reported that eIF5A activity is necessary for nerve growth factor-induced differentiation of PC12 cells and for neurite outgrowth in cultured hippocampal neurons (Huang et al., 2007), which suggests that eIF5A facilitates the translation of proteins that are involved in axonogenesis.

Here, we show that eIF5A activation leads to increased translation of $\mathrm{p} 35$, which in turn leads to activation of the small serine/ threonine kinase cyclin-dependent kinase 5 (Cdk5). p35 is one of two regulatory subunits that stimulates Cdk5 kinase activity, the other being p39, and both proteins are expressed exclusively in CNS neurons (Tsai et al., 1994; Tang et al., 1995). Cdk5 has a broader pattern of expression, but it is predominantly observed in the CNS due to the presence of p35 and p39 in neurons (Tsai et al., 1993). Once activated, Cdk5 phosphorylates a wide range of substrates such as microtubule-associated proteins, Tau, synapsin 1, and DARPP32 (Dhavan and Tsai, 2001), and has therefore been implicated in a variety of neuronal processes, including neurite outgrowth (Nikolic et al., 1996), synaptogenesis (Johansson et al., 2005), and neuronal migration in the developing cerebral cortex (Zhao et al., 2009). A variety of extracellular stimuli have been shown to activate Cdk5 including neurotrophins, dopamine, and integrins (Bibb et al., 2001; Harada et al., 2001), and we now show that polyamines can have this effect as well.

In this paper, we describe a novel signaling mechanism in which hypusination of eIF5A results in increased translation of p35, induction of Cdk5 activity, and reversal of MAG- and myelin-mediated inhibition of axonal growth. To the best of our knowledge, our observation that p35 is translated in response to eIF5A activation is the first description of eIF5A's downstream effects in neurons, which provides new insight into eIF5A's function in the nervous system and the intracellular signaling events that result in activation of Cdk5. Furthermore, we demonstrate that eIF5A, p35, and Cdk5 are all required to overcome inhibition of neurite outgrowth by myelin, which identifies these proteins as potential therapeutic targets for enhancing axonal regeneration following spinal cord injury and other forms of CNS trauma.

\section{Materials and Methods}

All animal procedures were approved by the Institutional Animal Care and Use Committee of Hunter College, City University of New York. The experiments were performed in accordance with all institutional and national regulations. Animals of both sexes were used in all experiments.

\section{Neuronal preparations}

Cerebellar granule neurons. Cerebellar cortex was isolated from postnatal day 5 (P5)-P7 Long-Evans rats and treated with $0.025 \%$ trypsin for 20 min at $37^{\circ} \mathrm{C}$. Trypsinization was terminated by the addition of DMEM (Invitrogen) containing 10\% fetal bovine serum (FBS; Invitrogen), and the tissue was mechanically dissociated. Cells were centrifuged at 1000 rpm for 5 min at $4^{\circ} \mathrm{C}$, resuspended in SATO media (Cai et al., 1999), and counted using a hemocytometer.

DRG neurons. DRG were isolated from P5-P8 Long-Evans rats and incubated in L15 media containing of $0.025 \%$ trypsin and $0.15 \%$ collagenase type I (Worthington) for $90 \mathrm{~min}$ at $37^{\circ} \mathrm{C}$. The ganglia were then triturated and trypsinization was stopped by the addition of DMEM containing 10\% FBS. Cells were centrifuged at $1000 \mathrm{rpm}$ for $5 \mathrm{~min}$ and resuspended in SATO before counting.

Cortical neurons. Cerebral cortices from P0-P2 Long-Evans rats were collected in plain Neurobasal-A media (Invitrogen) and treated twice with $0.5 \mathrm{mg} / \mathrm{ml}$ papain at $37^{\circ} \mathrm{C}$ for $20 \mathrm{~min}$ ( $40 \mathrm{~min}$ total). Papain was inhibited by the addition of soybean trypsin inhibitor, and the tissue was washed twice with plain Neurobasal-A media. The tissue was then triturated in Neurobasal-A media and strained through a $40 \mu \mathrm{m}$ cell strainer. Cell suspensions were layered on an Optiprep density gradient (Sigma) and centrifuged at $1900 \times g$ for $15 \mathrm{~min}$. Fractions containing enriched populations of neurons were pelleted by centrifugation and the neurons were resuspended in Neurobasal-A media supplemented with 1X B27 (Invitrogen), $0.5 \mathrm{~mm}$ L-glutamine (Invitrogen), and $1 \times$ antibioticantimycotic (Invitrogen) before counting.

\section{Neuronal treatments}

Pharmacological agents. Twenty-four-well plates were coated with 20 $\mu \mathrm{g} / \mathrm{ml}$ poly-L-lysine (PLL; Sigma) for $30 \mathrm{~min}$ at room temperature and air dried. Depending on the nature of the experiment, purified neurons received one or more of the following treatments: dibutyryl cAMP (dbcAMP; 1 mm; Calbiochem), putrescine (100 $\mu$ m; Sigma), roscovitine (10 $\mu \mathrm{M}$; Sigma), N1-guanyl-1,7-diaminoheptane (GC-7; $1 \mu \mathrm{M}$ or $10 \mu \mathrm{M}$; a gift from Dr. Solomon H. Snyder, Johns Hopkins University School of Medicine, Baltimore, MD), 5,6-dicholro-1- $\beta$-Dribofuranosylbenzimidazole (DRB; $5 \mu \mathrm{M}$; Sigma), cycloheximide $(0.5$ $\mu \mathrm{g} / \mathrm{ml}$; Sigma), BDNF (200 ng/ml; Sigma), or U0126 (1,4-diamino-2,3dicyano-1,4-bis(o-aminophenylmercapto)butadiene monoethanolate; $10 \mu \mathrm{m}$; Sigma). Cells were plated at a density of $1 \times 10^{6}$ cells/well. For neurite outgrowth assays, cells were incubated at $37^{\circ} \mathrm{C}$ for $18-24 \mathrm{~h}$, washed once with $1 \times \mathrm{PBS}$, and then treated with $0.1 \%$ trypsin. After a 5 min incubation, trypsinization was stopped by the addition of DMEM containing 10\% FBS. Neurons were triturated, centrifuged at $1000 \mathrm{rpm}$ for $5 \mathrm{~min}$, resuspended in SATO media, and plated onto either $\mathrm{CHO}$ cell monolayers or CNS myelin substrates. For Western blot analysis, cells were incubated for $1-24 \mathrm{~h}$ as indicated in the experiment and then lysed in $1 \times$ RIPA lysis buffer (Millipore) supplemented with phosphatase inhibitors $\left(1 \mathrm{~mm} \mathrm{Na} \mathrm{VO}_{4}, 1 \mathrm{~mm} \mathrm{NaF}\right.$ ) and protease inhibitors $(1 \mathrm{~mm}$ EDTA, $1 \mathrm{~mm}$ PMSF, and $1 \mu \mathrm{g} / \mathrm{ml}$ aprotinin, leupeptin, and pepstatin).

HSV transduction. DRG neurons were plated on PLL-coated 24-well plates at a density of $1 \times 10^{6}$ cells/well and transduced with HSV expressing dominant negative Cdk5-GFP (DNCdk5), p35, or LacZ at a final concentration of $10^{7} \mathrm{PFU} / \mathrm{ml}$. The viruses were obtained from Dr. R. Neve, Director of the Viral Gene Transfer core at the Massachusetts Institute of Technology. Cells were maintained in virus-containing media overnight at $37^{\circ} \mathrm{C}$ and treated with dbcAMP or putrescine as described above. Neurons were then transferred to $\mathrm{CHO}$ cell monolayers for neurite outgrowth assays or lysed in $1 \times$ RIPA buffer for Western blot analysis.

siRNA. Custom siRNAs for the sense strand of rat deoxyhypusine synthase (DHS) and eIF5A were obtained from Dharmacon. The siRNA duplexes were synthesized with a thiol modification on the sense strand and purified by HPLC. The sequences for the siRNAs and their corresponding scrambled siRNAs were as follows: DHS, GCCCAUAAGAAC CACAUAC; scrambled, CCAUUAAACCCGGCCAAAA; eIF5A, AAAG 
GAAUGAUUUCCAGCUGA; scrambled, CGUUAUGACGAAACAGA AGUU. Annealed siRNA duplexes were resuspended in RNase-free water. An equimolar ratio of Penetratin I (Q-Biogene) was added, and the mixture was incubated at $65^{\circ} \mathrm{C}$ for $15 \mathrm{~min}$ and then further incubated at $37^{\circ} \mathrm{C}$ for $1 \mathrm{~h}$. The penetratin-coupled siRNAs were then added to cerebellar neurons at a concentration of $300 \mathrm{~nm}$ and the neurons were incubated for $24-28 \mathrm{~h}$. Neurons were then treated with putrescine as described above and lysed for Western blot analysis or used for neurite outgrowth assays.

siRNA rescue experiment. The following custom siRNA for the 3'UTR of eIF5A and its corresponding scrambled siRNA were obtained from Dharmacon: eIF5A 3'UTR, GCUGGACUCCUAUCCAAUUUA; scrambled, UUUUUAAAAAAAGGGGGGCCC. siRNAs were coupled to penetratin and incubated with P5-6 DRG rat neurons as described above.

To rescue eIF5A expression, siRNA-transduced neurons were transiently transfected with an ORF clone expressing eGFP-tagged human eIF5A (EX-H4019-M29; Genecopoeia). Transfections were performed using the Amaxa Rat Neuron Nucleofector kit (Lonza) at a concentration of $1-2 \mu \mathrm{g}$ DNA $/ 10^{6}$ cells. Transfected neurons were then used for neurite outgrowth assays.

\section{Neurite outgrowth assay}

CHO cell monolayers. Permanox eight-well chamber slides (Lab-Tek) were coated with $20 \mu \mathrm{g} / \mathrm{ml}$ poly-L-lysine (Sigma) for $30 \mathrm{~min}$ at room temperature followed by $20 \mu \mathrm{g} / \mathrm{ml}$ fibronectin (Sigma) for $2 \mathrm{~h}$ at $37^{\circ} \mathrm{C}$. Control or MAG-expressing $\mathrm{CHO}$ cells were plated in the wells at a concentration of 75,000 cells/well and grown to confluency overnight.

CNS myelin substrates. CNS myelin was purified from adult rat medulla as described previously (Norton and Poduslo, 1973). Myelin solutions containing $0.5-2.0 \mu \mathrm{g}$ total protein/well were plated in the wells of eight-well PLL-coated chamber slides and desiccated overnight.

Assay. Neurons were plated at a density of 15,000 cells/well and incubated at $37^{\circ} \mathrm{C}$ for $18-24 \mathrm{~h}$. Cells were fixed for $30 \mathrm{~min}$ with $4 \%$ paraformaldehyde, permeabilized with ice-cold methanol, and blocked for 30 min at room temperature with DMEM containing 10\% FBS. Cells were then incubated overnight at $4^{\circ} \mathrm{C}$ with mouse monoclonal anti- $\beta$ III tubulin antibody (Tuj1, 1:1000; Biolegend, catalog \#801201) diluted in 5\% BSA in PBS. Cells were washed three times with $1 \times$ PBS and then incubated for $30 \mathrm{~min}$ at room temperature with biotinylated sheep antimouse IgG (1:500; GE Healthcare, catalog \#RPN1001), followed by incubation with streptavidin-conjugated Texas Red (1:300; GE Healthcare, catalog \#RPN1233-2ML) for $45 \mathrm{~min}$. The slides were mounted with Permafluor (Thermo Fisher Scientific), and images were taken with a fluorescence microscope. A minimum of three independent experiments were performed for each neurite outgrowth assay, and in each experiment the length of the longest neurite for each neuron was measured for a minimum of 200 neurons per treatment using MetaMorph image analysis software (Molecular Devices).

\section{Western blotting}

Protein concentrations were measured using the Bio-Rad DC protein assay, and SDS-PAGE was performed using $10 \%$ polyacrylamide gels. Proteins were transferred to nitrocellulose and membranes were blocked in 5\% nonfat dry milk in PBS containing 0.1\% Tween-20 (Sigma). Membranes were probed with the following primary antibodies: rabbit anti-p35 (1:1000; Santa Cruz Biotechnology, catalog \#sc-820), rabbit anti-Cdk5 (1:1000; Santa Cruz Biotechnology, catalog \#sc-173), rabbit anti-phospho Erk1/2 (Thr202/Tyr204, 1:1000; Cell Signaling Technology, catalog \#9101), rabbit anti-Erk1/2 (1:1000; Cell Signaling Technology, catalog \#9102), rabbit-anti DHS (1:1000; Santa Cruz Biotechnology, catalog \#sc-67161), mouse anti-eIF5A (1:1000; BD Biosciences, catalog \#611976), mouse monoclonal anti- $\beta$ III tubulin antibody (Tuj1, 1:1000; Biolegend, catalog \#801201), and rabbit anti-actin (1: 1000; Sigma, catalog \#A2066) in blocking buffer overnight at $4^{\circ} \mathrm{C}$. Membranes were washed three times in PBS with $0.1 \%$ Tween- 20 and incubated with one of the following secondary antibodies for $1 \mathrm{~h}$ at room temperature: horseradish peroxidase (HRP)-conjugated anti-rabbit IgG (1:2000; Cell Signaling Technology) or HRP-conjugated anti-mouse IgG
(1:2000; Cell Signaling Technology). Proteins were visualized using ECL (GE Healthcare). Membranes were subsequently stripped with Restore Western blot stripping buffer (Thermo Fisher Scientific) for $30 \mathrm{~min}$ at room temperature and reprobed as indicated. Densitometric measurements were made using ImageJ software (NIH).

\section{Cdk5 kinase assay}

Cell lysates were incubated with rabbit anti-Cdk5 antibody (Santa Cruz Biotechnology, catalog \#sc-173) overnight at $4^{\circ} \mathrm{C}$, and Cdk5 was then immunoprecipitated from the lysates using protein $\mathrm{G}$ Sepharose beads (Santa Cruz Biotechnology). The beads were washed twice with $1 \times$ RIPA lysis buffer and once with kinase reaction buffer (50 mM HEPES, $\mathrm{pH} 7.55$, $10 \mathrm{mM} \mathrm{MgCl}_{2}$, and $1 \mathrm{~mm}$ dithiothreitol, phosphatase, and protease inhibitors). The washed beads were mixed with $10 \mu \mathrm{g}$ of histone $\mathrm{H} 1$ in kinase reaction buffer with $2 \mu \mathrm{Ci} \gamma^{-}{ }^{32} \mathrm{P}$ ATP and incubated for $30 \mathrm{~min}$ at $30^{\circ} \mathrm{C}$. The reaction was stopped by the addition of sample buffer $(62.5 \mathrm{~mm}$ Tris-HCl, pH 6.8 and 2\% SDS). SDS-PAGE was performed using $10 \%$ polyacrylamide gels, and radiolabeled proteins were visualized using autoradiography.

\section{Immunocytochemistry}

Purified cortical neurons were plated in PLL-coated chamber slides and incubated with $100 \mu \mathrm{m}$ putrescine for 5, 9, 13, or $17 \mathrm{~h}$. The cells were fixed with $4 \%$ paraformaldehyde, blocked for $30 \mathrm{~min}$ at room temperature with DMEM containing 10\% FBS, and incubated with rabbit anti-p35 (1:50; Santa Cruz Biotechnology) and mouse-anti Cdk5 (1:100; Millipore) antibodies overnight at $4^{\circ} \mathrm{C}$ in $5 \%$ BSA in PBS. Cells were rinsed with $1 \times \mathrm{PBS}$ and then incubated for $1 \mathrm{~h}$ at room temperature with Texas Red-conjugated anti-mouse IgG and fluorescein isothiocyanteconjugated anti-rabbit IgG. Slides were coverslipped with Permafluor and viewed under fluorescence optics.

\section{Statistical analysis}

GraphPad Prism software was used to perform all statistical analyses, and data are presented as mean \pm SEM. One-way ANOVAs were performed, followed by Tukey posttests for multiple comparisons.

\section{Results}

\section{Activation of Cdk5 is required for both dbcAMP and polyamines to overcome inhibition by MAG}

Previous studies from our laboratory have demonstrated that treatment with dbcAMP enhances neurite outgrowth in the presence of myelin-associated inhibitors (Cai et al., 1999) and that dbcAMP overcomes inhibition by MAG and CNS myelin by inducing expression of arginase I, which in turn leads to increased synthesis of polyamines (Cai et al., 2002). We have also shown that the polyamine putrescine can overcome inhibition by MAG when administered in vitro (Cai et al., 2002; Deng et al., 2009), but the molecular events underlying its effects have not yet been defined. In this study, we now show that the ability of both dbcAMP and polyamines to overcome MAG-mediated inhibition is dependent on Cdk5 activity. Neurite outgrowth was strongly inhibited for both cerebellar granule neurons (CGNs; Fig. 1A) and DRG neurons ( $B$ ) plated on monolayers of MAG-expressing $\mathrm{CHO}$ cells, and treatment with $1 \mathrm{~mm}$ dbcAMP reversed this inhibition, leading to significant increases in neurite length $(C)$. However, in the presence of the Cdk5-selective inhibitor roscovitine $(10 \mu \mathrm{M})$, the effects of dbcAMP were completely abolished (Fig. $1 A-C$ ). Similarly, CGNs and DRG neurons primed with $100 \mu \mathrm{M}$ putrescine for $18 \mathrm{~h}$ were able to overcome inhibition by MAG, and this effect was lost when roscovitine was administered in conjunction with putrescine (Fig. 2A). Roscovitine also negated the growth-promoting effects of putrescine when DRG neurons were plated on CNS myelin substrates (Fig. 2B), which shows that this phenomenon is not MAG-specific and that Cdk5 activity is required to overcome all myelin-associated inhibi- 
A
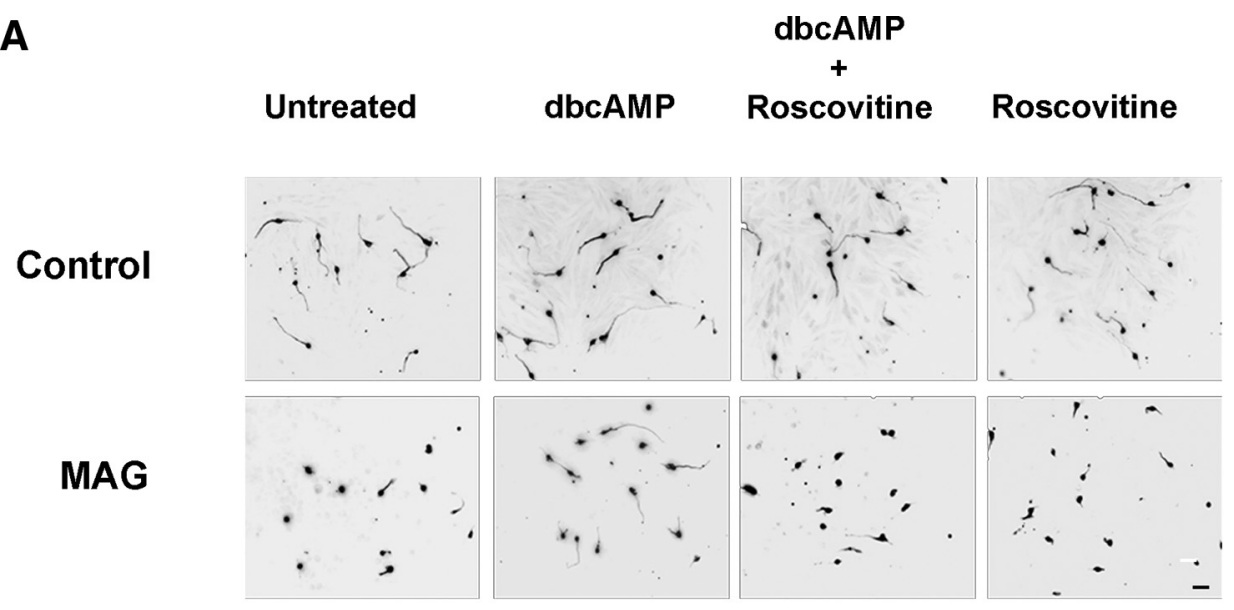

B

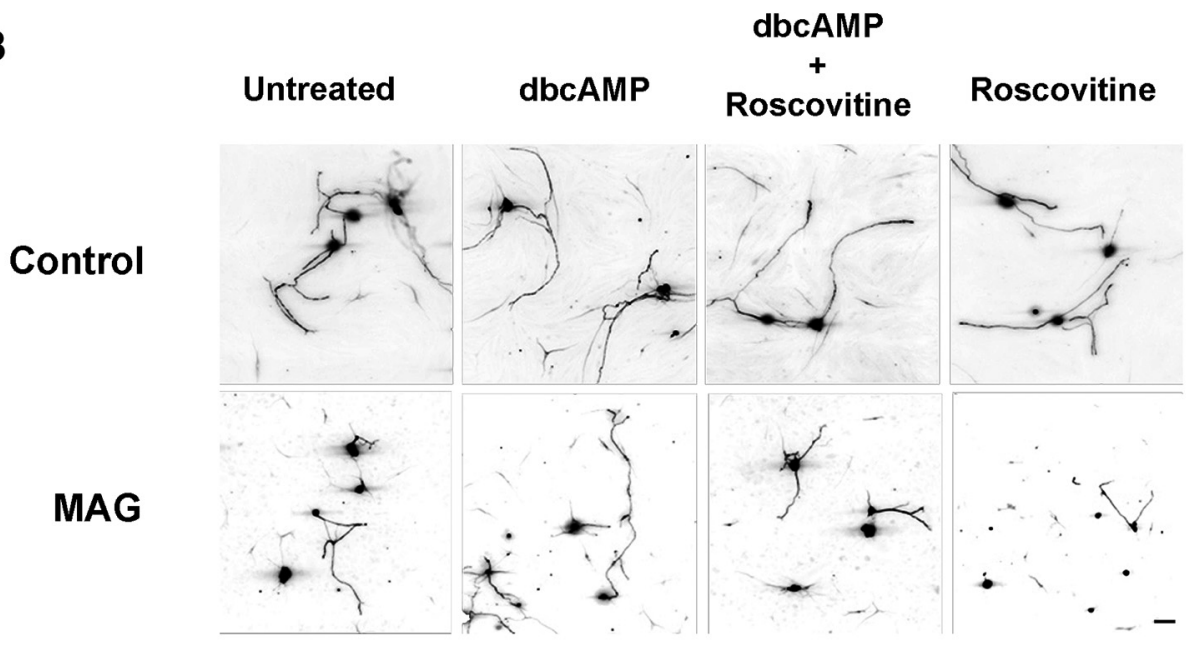

C
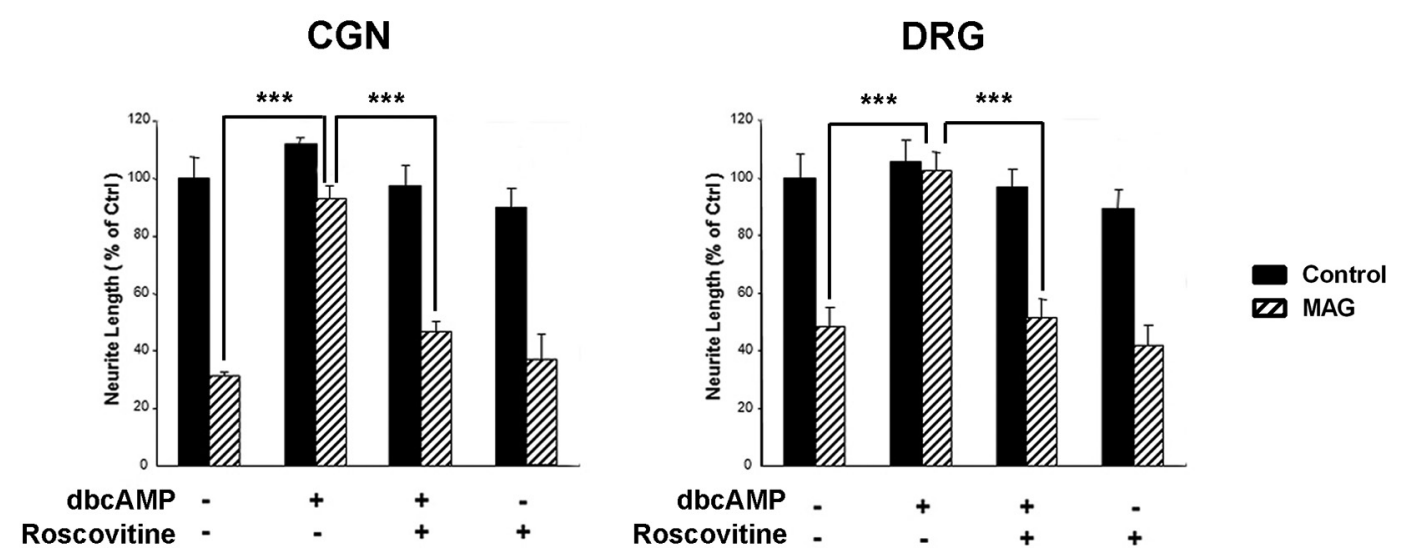

Figure 1. C $\mathrm{dk} 5$ activity is required for the ability of dbcAMP to overcome inhibition by MAG. $A$, Representative images of CGNs treated with $1 \mathrm{~mm}$ dbcAMP and $10 \mu \mathrm{m}$ roscovitine and plated on monolayers of control or MAG-expressing CHO cells. $\boldsymbol{B}$, Representative images of DRG neurons treated with $1 \mathrm{~mm} \mathrm{dbcAMP}$ and $10 \mu \mathrm{m}$ roscovitine plated on monolayers of control or MAG-expressing CHO cells. Scale bars: $A, 20 \mu \mathrm{m} ; \boldsymbol{B}, 30 \mu \mathrm{m}$. C, Neurite outgrowth was measured from a minimum of 200 neurons for each treatment. Graphs represent the average length of the longest neurite per neuron (depicted as percentage of control) \pm SEM. ${ }^{* * *} p<0.001$.

tors. In all experiments, neurons treated with roscovitine alone displayed neurite outgrowth that was comparable to that observed for untreated controls (Figs. 1C, $2 A, B$ ), which indicates that $10 \mu \mathrm{M}$ roscovitine had no toxic effects and also that Cdk5 activity is not required for basal neurite outgrowth.

Last, to provide further evidence that activation of Cdk5 is necessary to overcome inhibition by MAG, DRG neurons were transduced with HSV expressing either LacZ or a dominant negative form of Cdk5 (DNCdk5) that is mutated at N144 (Zukerberg et al., 2000; Fig. 2C). Neurons were then treated with either dbcAMP or putrescine and plated on $\mathrm{CHO}$ cell monolayers. For LacZ-transduced neurons, dbcAMP and putrescine both overcame inhibition by MAG (Fig. 2D,E); however, for neurons expressing DNCdk5, the effects of dbcAMP and putrescine were 
A

CGN

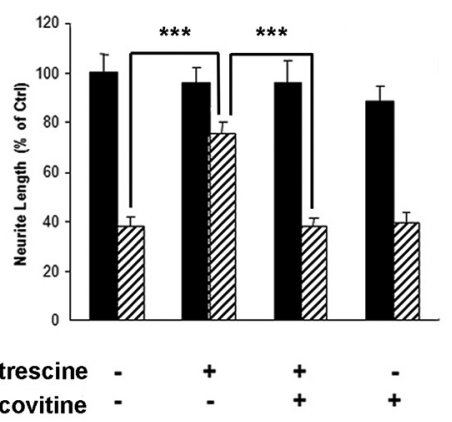

DRG

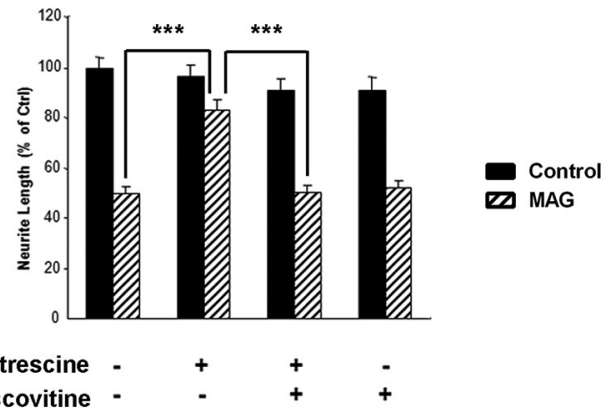

B

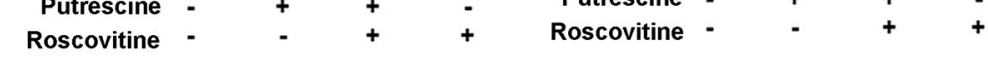

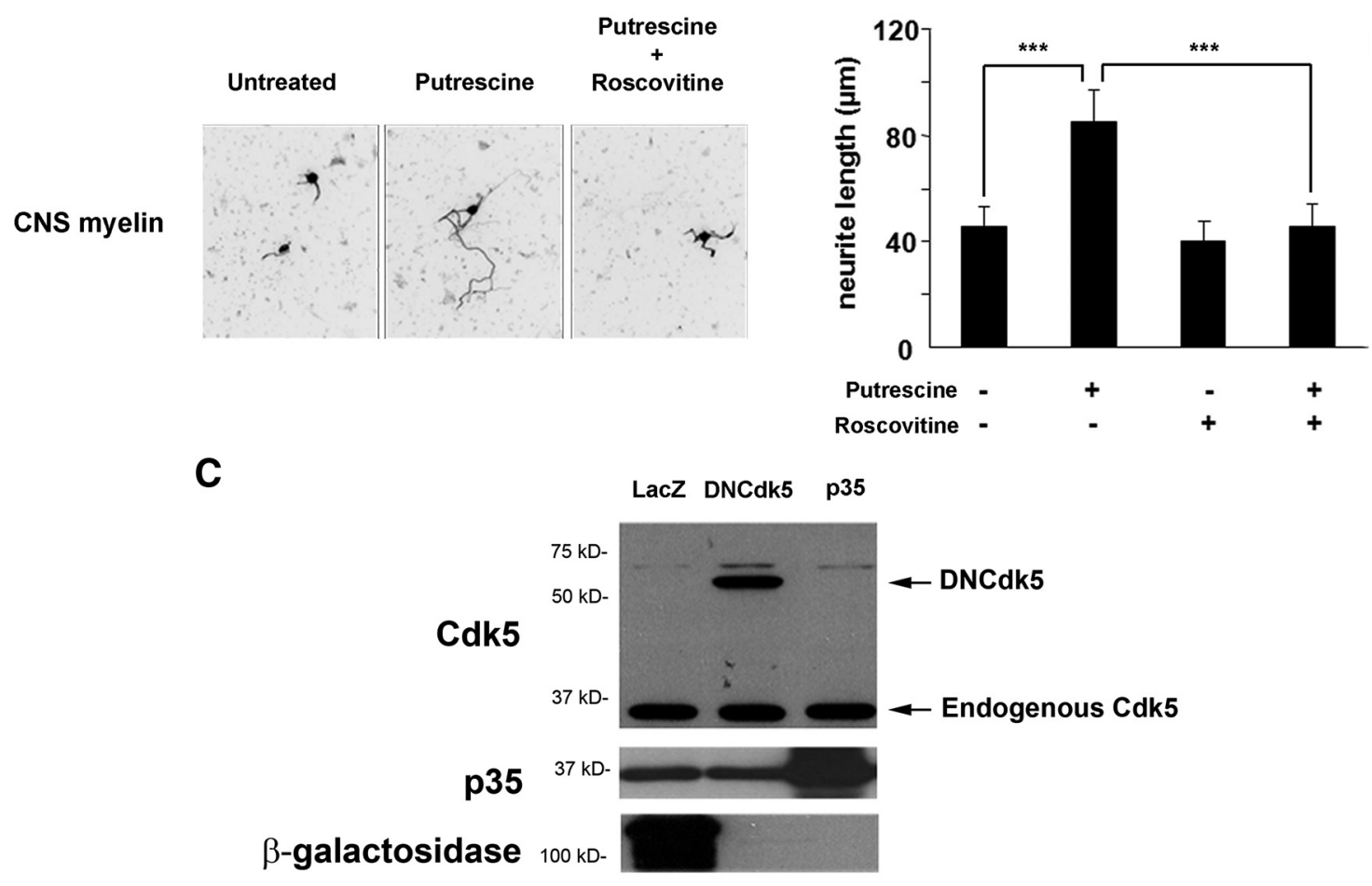

D

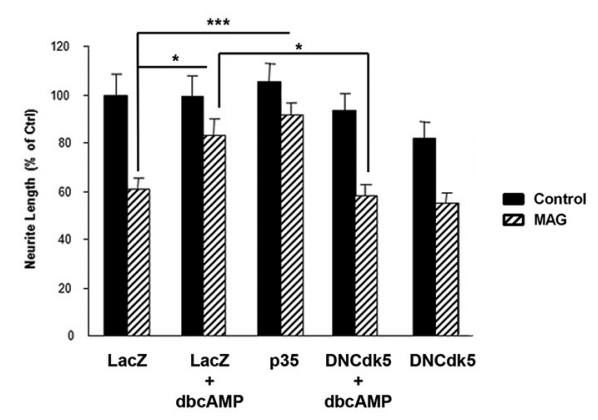

E

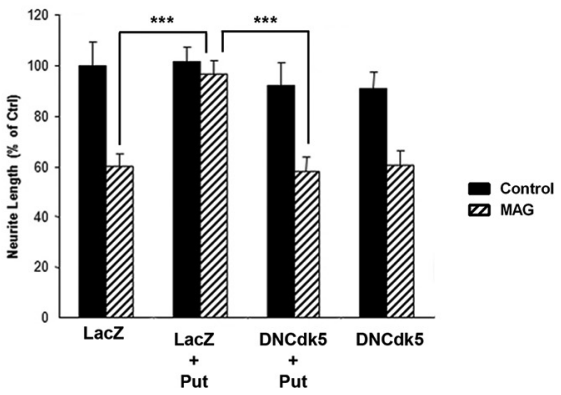

Figure 2. Loss of Cdk5 activity blocks the ability of dbcAMP and putrescine to overcome inhibition by myelin-associated inhibitors. $A$, Quantification of neurite outgrowth for CGNs and DRG neurons primed with $100 \mu \mathrm{m}$ putrescine and $10 \mu \mathrm{m}$ roscovitine and plated on monolayers of control or MAG-expressing CHO cells. $\boldsymbol{B}$, Representative images and quantification of neurite outgrowth for DRG neurons primed with $100 \mu \mathrm{m}$ putrescine and $10 \mu \mathrm{m}$ roscovitine and plated on CNS myelin. C, Western blot of DRG neurons transduced with HSV expressing LacZ, p35, or dominant negative Cdk5 (DNCdk5). D, Quantification of neurite outgrowth for DRG neurons transduced with HSV expressing LacZ, p35, and DNCdk5, treated with 1 mM dbcAMP and plated on monolayers of control or MAG-expressing CHO cells. E, Quantification of neurite outgrowth for DRG neurons transduced with HSV expressing LaCZ and DNCdk5, treated with $100 \mu \mathrm{m}$ putrescine and plated on monolayers of control or MAG-expressing $\mathrm{CHO}$ cells. For all experiments, neurite outgrowth was measured from a minimum of 200 neurons for each treatment. Graphs represent the average length of the longest neurite per neuron (depicted as percentage of control) \pm SEM. ${ }^{*} p<0.05 ;{ }^{* * *} p<0.001$.

abolished, and neurite outgrowth on MAG-expressing $\mathrm{CHO}$ cells was significantly reduced (Fig. 2D,E). There was no effect on neurite outgrowth for neurons expressing LacZ or DNCdk5 alone (Fig. $2 D, E$ ), which once again indicates that basal neurite outgrowth is not affected by the loss of Cdk5 activity. Together, these results demonstrate that the ability of dbcAMP and putrescine to overcome inhibition by MAG and myelin is dependent on the activation of Cdk5. 
A

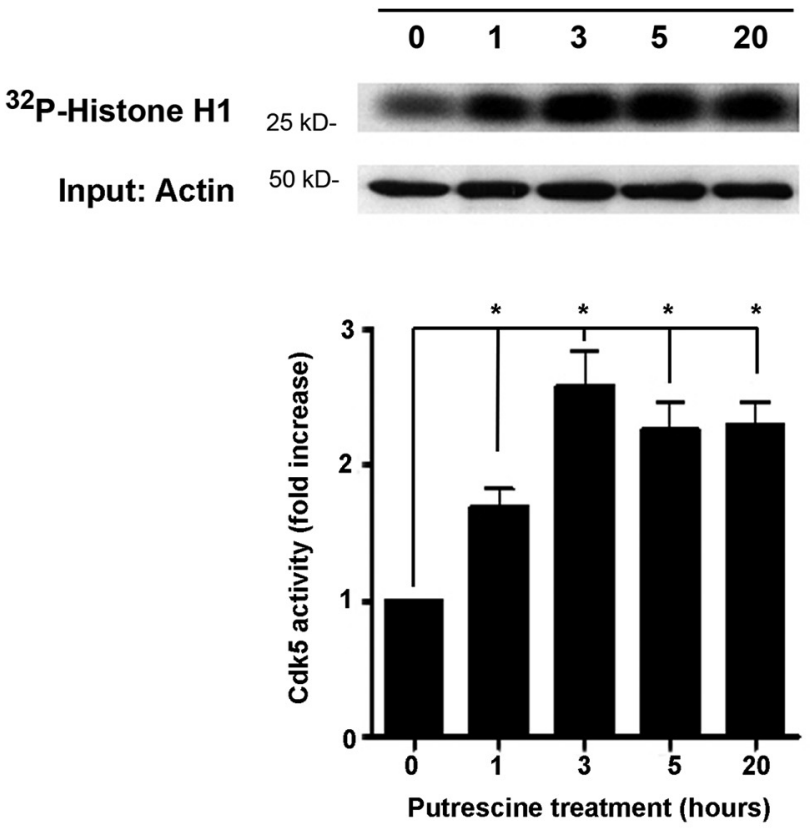

B

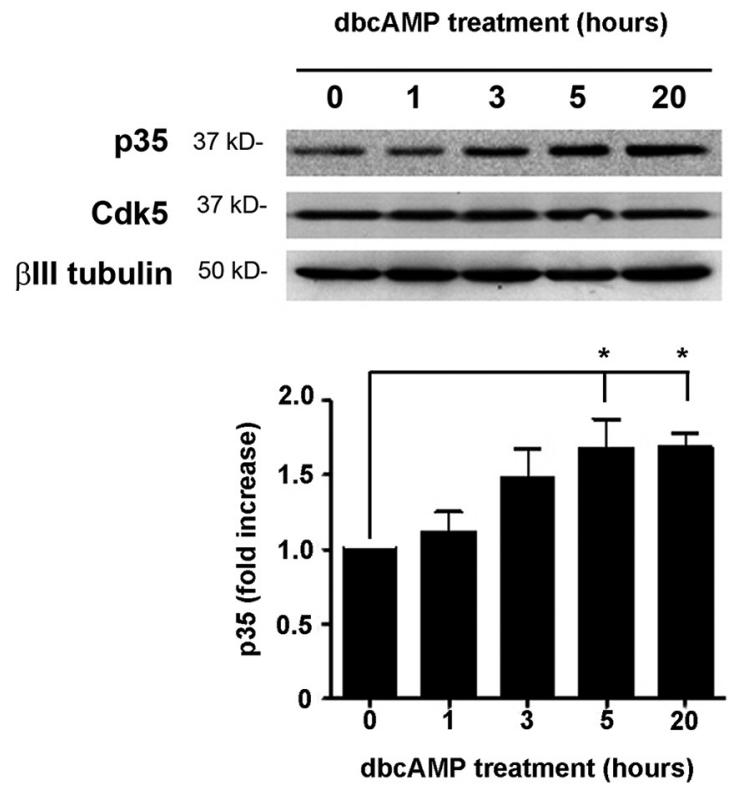

C

Putrescine treatment (hours)
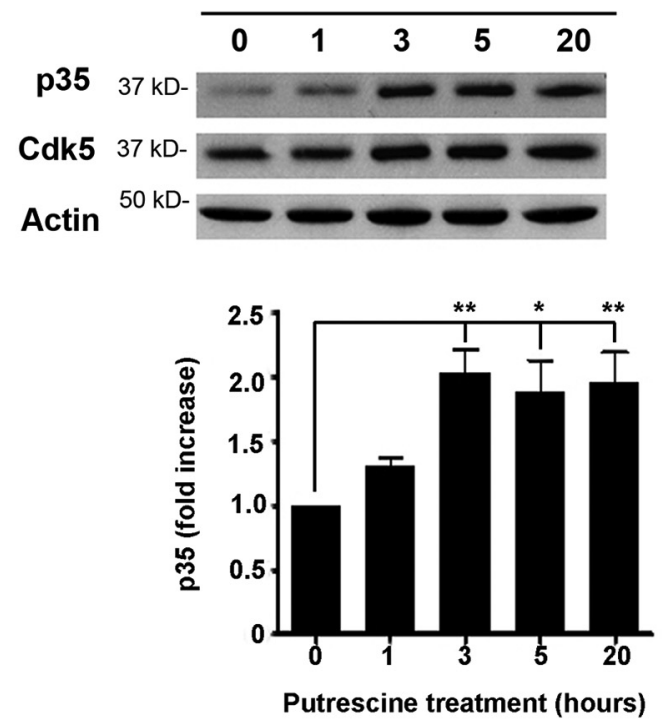

Figure 3. Putrescine induces Cdk5 activity and p35 expression. $A$, Representative images of a Cdk5 kinase assay $(n=3)$. CGNs were treated with $100 \mu \mathrm{m}$ putrescine for the times indicated, and Cdk5 was immunoprecipitated. Cdk5 activity was assessed by combining the immunoprecipitated Cdk5 with ${ }^{32} \mathrm{P}$ and histone $\mathrm{H} 1$ and measuring the incorporation of ${ }^{32} \mathrm{P}$ by autoradiography. $\boldsymbol{B}$, Western blots of CGNs treated with $1 \mathrm{~mm}$ dbcAMP for the times indicated $(n=5)$. C, Western blots of CGNs treated with $100 \mu \mathrm{m}$ putrescine for the times indicated $(n=3)$. Graphs represent densitometric measurements that have been normalized to the control ( $0 \mathrm{~h}$ time point) and depicted as average fold changes \pm SEM. ${ }^{*} p<0.05$; ${ }^{* *} p<0.01$.

Polyamines activate Cdk5 and activation of Cdk5 is sufficient to overcome inhibition by MAG

To build on these observations, we performed a Cdk5 kinase assay to determine whether putrescine could induce Cdk5 activity. CGNs were incubated with $100 \mu \mathrm{M}$ putrescine for 1,3 , 5, or $20 \mathrm{~h}$, and following lysis of the cells, Cdk5 was immunoprecipitated. The ability of the immunoprecipitated Cdk5 to phosphorylate histone-H1 was then assessed by measuring the amount of ${ }^{32} \mathrm{P}$ incorporated into the protein. After $1 \mathrm{~h}$ of putrescine treatment, we observed a significant increase in radiolabeled histone H1 (Fig. 3A), which was indicative of increased phosphorylation by the immunoprecipitated Cdk5. After $3 \mathrm{~h}$ of putrescine treatment, levels of phosphorylated histone $\mathrm{H} 1$ had increased by $\sim 2.5$-fold, and we continued to observe significant increases in kinase activity at the 5 and $20 \mathrm{~h}$ time points as well (Fig. 3A). This led us to conclude that putrescine induces a rapid and sustained activation of Cdk5 in cerebellar neurons.

In neurons, activation of Cdk5 is initiated by the binding of Cdk5 monomers to the neuron-specific activator protein, p35 (Lew et al. 1994; Tsai et al., 1994). Having observed that the effects of dbcAMP and putrescine are dependent on Cdk5 activity, our next goal was to determine whether p35-mediated acti- 


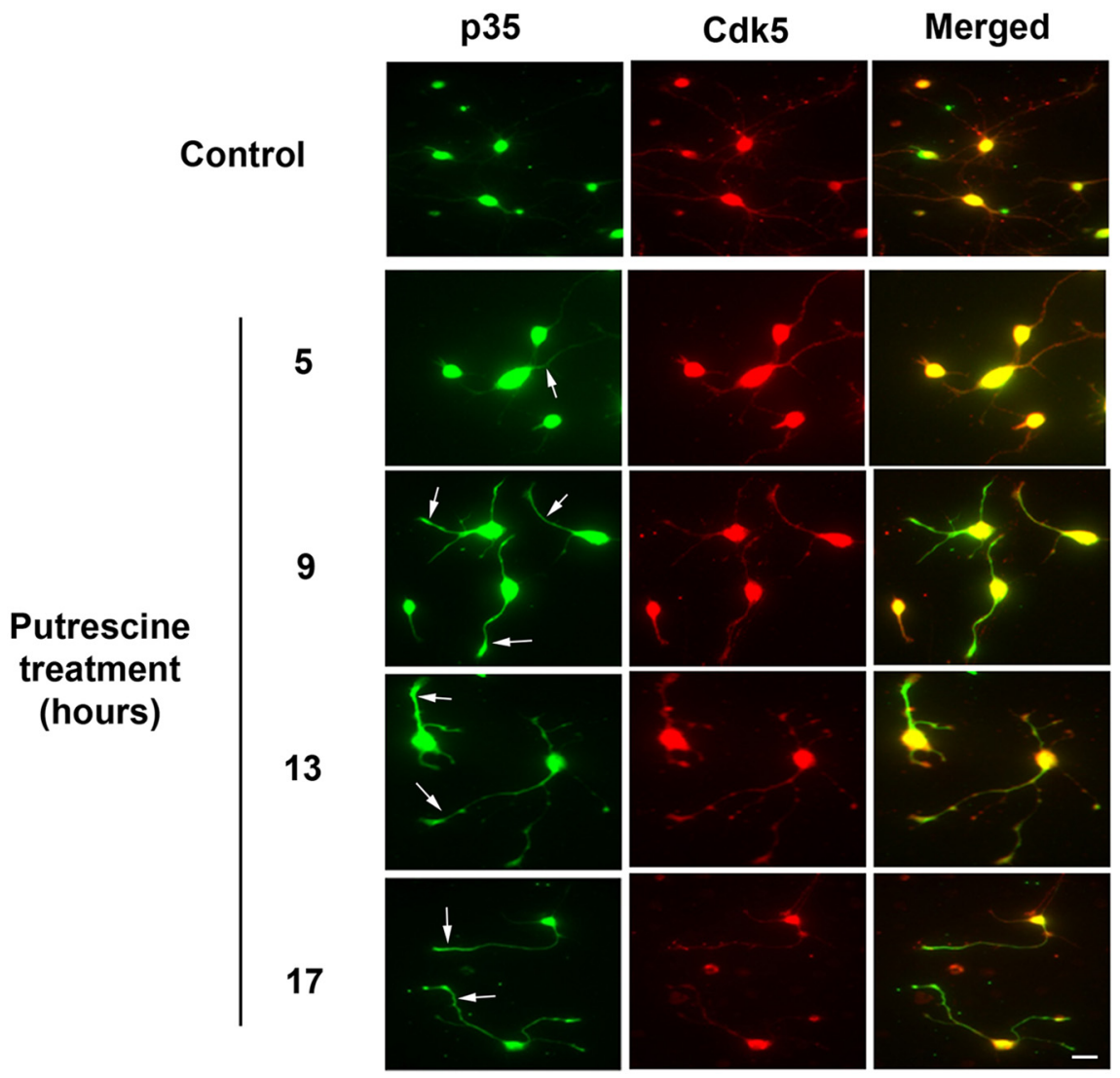

Figure 4. p35 is increased in response to putrescine and localizes to the neurites and growth cones of cortical neurons. Cortical neurons were treated with $100 \mu \mathrm{m}$ putrescine for the times indicated. Cells were immunostained for p35 (green) and Cdk5 (red). Arrows indicate the presence of $\mathrm{p} 35$ within neurites and growth cones. Scale bar, $20 \mu \mathrm{m}$.

vation of Cdk5 could reverse MAG-mediated inhibition. DRG neurons were transduced with HSV expressing p35 (Fig. 2C) and then plated on $\mathrm{CHO}$ cell monolayers. When compared to LacZexpressing controls, neurite outgrowth on MAG was significantly increased for neurons overexpressing p35 (Fig. 2D), and this effect was comparable to that seen in LacZ-transduced neurons that were treated with dbcAMP (Fig. 2D). These observations indicate that direct activation of $\mathrm{Cdk} 5$ through overexpression of p35 is sufficient to overcome inhibition by MAG and suggest that p35 may play an important role in this process.

\section{Polyamines increase the expression of p35}

To investigate the effects of polyamines and dbcAMP on p35 expression, CGNs were incubated with either $1 \mathrm{~mm}$ dbcAMP or $100 \mu \mathrm{M}$ putrescine for $1,3,5$, or $20 \mathrm{~h}$, and levels of p 35 and Cdk5 were then analyzed by Western blotting. In neurons treated with dbcAMP, p35 levels were significantly increased after $5 \mathrm{~h}$ and remained elevated after $20 \mathrm{~h}$ of treatment (Fig. 3B). Similarly, p35 levels were significantly increased by approximately twofold after a $3 \mathrm{~h}$ incubation with putrescine, and these increases were sustained at 5 and $20 \mathrm{~h}$ after treatment (Fig. 3C). Cdk5 levels, however, were unchanged in response to dbcAMP and putrescine in these experiments (Fig. $3 B, C$ ). These results demonstrate that dbcAMP and its downstream effector putrescine can increase the expression of $\mathrm{p} 35$ protein in cerebellar neurons. It is important to note that the incubation times that produced these increases are consistent with those used in the Cdk5 kinase assay and neurite outgrowth assays, and so it is likely that these increases in p35 underlie the ability of putrescine to induce activation of Cdk5 and overcome inhibition by MAG.

It has been reported that in neurons with actively growing processes, $\mathrm{p} 35$ associates with Cdk5 within the neurites and growth cones (Nikolic et al., 1996). We therefore examined how putrescine treatment affects the subcellular distribution of p35 using P0-P2 cortical neurons, which have large growth cones that are readily visualized. The neurons were incubated with $100 \mu \mathrm{M}$ putrescine for $5,9,13$, or $17 \mathrm{~h}$, and were then fixed and immunostained for p35 and Cdk5. In untreated controls, p35 was observed almost exclusively in the cell bodies, whereas Cdk5 was present in both the cell bodies and neurites (Fig. 4). Following treatment with putrescine, the amount of Cdk5 within the neurites remained consistent, but beginning at $9 \mathrm{~h}$ after treatment, we observed a dramatic and sustained increase in the amount of p35 in the neurites, and accumulation of p35 in the growth cones was also readily apparent (Fig. 4, arrows). When the p35 and Cdk5 immunostained images were merged, we observed extensive colocalization of p35 and $\mathrm{Cdk} 5$ within the neurites, which indicates that these two proteins are in a proper position to interact with each other. These results support our biochemical data showing that putrescine increases p35 expression, and they also demonstrate that in response to putrescine treatment, p35 localizes to neurites and growth cones where it can activate Cdk5 and enhance process outgrowth.

\section{Putrescine increases the expression of p35 in a translation- dependent manner}

It was reported previously that $\mathrm{p} 35$ expression and Cdk5 activation are increased in CGNs in response to BDNF and that BDNF mediates this effect through the Erk signaling pathway (Harada et al., 2001). To determine whether a similar mechanism was responsible for putrescine-induced expression of p35, we tested whether treatment with putrescine leads to increased phosphorylation of Erk1/2. As in our previous experiments (Fig. 3C), we observed a time-dependent increase in p35 when CGNs were treated with putrescine, but whereas Erk1/2 phosphorylation was dramatically increased in neurons treated with $200 \mathrm{ng} / \mathrm{ml}$ BDNF for $30 \mathrm{~min}$, there was no induction of Erk1/2 phosphorylation in response to putrescine at any of the time points that were analyzed (Fig. $5 A$ ). Furthermore, treatment with the Erk1/2 inhibitor U0126 had no effect on the ability of putrescine to induce p35 expression (Fig. 5A). We therefore concluded that putrescine does not induce Erk phosphorylation and that Erk signaling is likely not involved in putrescine-induced expression of p35 and activation of Cdk5.

Having eliminated Erk signaling as a possible mechanism, we next investigated the broader roles of transcription and translation in putrescine-mediated expression of p35. CGNs were treated with $100 \mu \mathrm{M}$ putrescine in the presence of either 
A

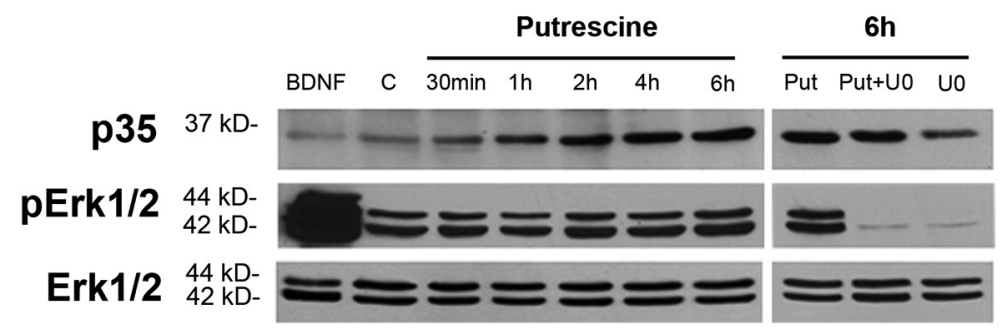

B

C
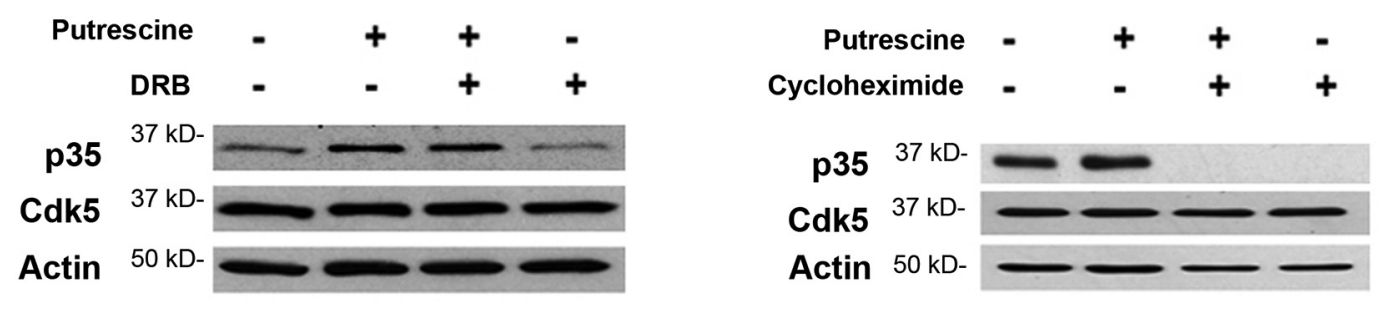

D

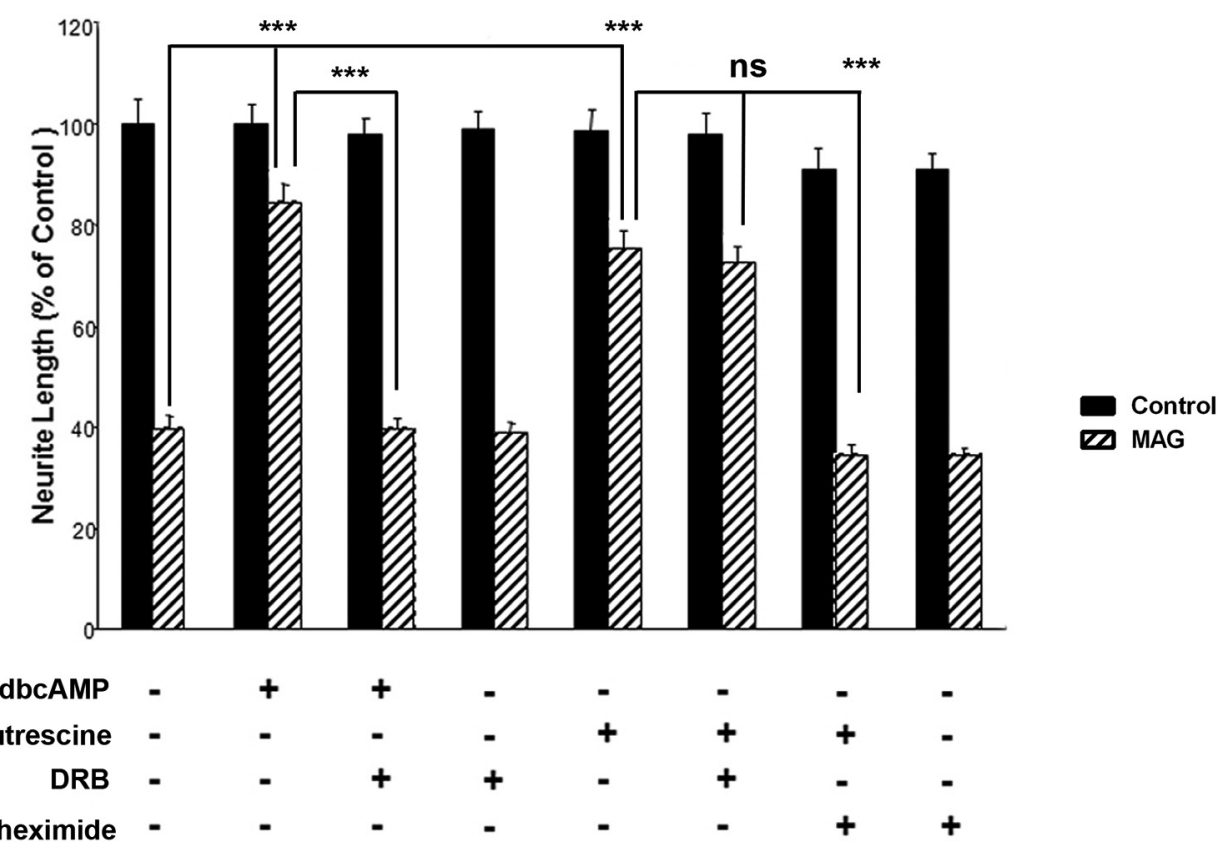

Figure 5. Putrescine-mediated induction of $\mathrm{p} 35$ expression and reversal of MAG-mediated inhibition are translation dependent. $A$, Western blots of CGNs treated with $200 \mathrm{ng} / \mathrm{ml}$ BDNF, $100 \mu \mathrm{M}$ putrescine, and $10 \mu \mathrm{m}$ U0126 for the times indicated. $\boldsymbol{B}$, Western blots of CGNs treated with $100 \mu \mathrm{m}$ putrescine and $5 \mu \mathrm{m}$ DRB for $20 \mathrm{~h}$. C, Western blots of CGNs treated with $100 \mu \mathrm{m}$ putrescine and $0.5 \mu \mathrm{g} / \mathrm{ml}$ cycloheximide for $20 \mathrm{~h}$. D, Quantification of neurite outgrowth for CGNs primed with $1 \mathrm{~mm} \mathrm{dbcAMP,} 100 \mu \mathrm{m}$ putrescine, $5 \mu \mathrm{m} \mathrm{DRB}$, and $0.5 \mu \mathrm{g} / \mathrm{ml}$ cycloheximide and plated on monolayers of control or MAG-expressing $\mathrm{CHO}$ cells. Neurite outgrowth was measured from a minimum of 200 neurons for each treatment. The graph represents the average length of the longest neurite per neuron (depicted as percentage of control) \pm SEM. ${ }^{* * *} p<0.001$. ns, Not significant.

the transcriptional inhibitor DRB $(5 \mu \mathrm{M})$ or the translational inhibitor cycloheximide $(0.5 \mu \mathrm{g} / \mathrm{ml})$, and p35 levels were analyzed by Western blotting. After a $20 \mathrm{~h}$ incubation with putrescine alone, there was a visible increase in p 35 protein, and this increase was not affected by the inclusion of DRB (Fig. $5 B$ ), which suggests that the effects of putrescine are transcription independent. By contrast, when the neurons were treated with a combination of putrescine and cycloheximide, putrescine-induced expression of p35 was completely blocked (Fig. $5 C$ ), thereby demonstrating that the ability of putrescine to increase p35 expression is translation dependent. Interestingly, p35 expression was also abolished in CGNs treated with cycloheximide alone (Fig. 5C), which suggests that there is a rapid turnover of p35 within neurons and that new protein is produced through translation.

We then performed neurite outgrowth assays to determine whether translation was also required for putrescine-treated neurons to overcome inhibition by MAG. Consistent with our previous study showing that the effects of dbcAMP are transcription dependent (Cai et al., 2002), we first showed that DRB can block 
the reversal of MAG-mediated inhibition by dbcAMP (Fig. 5D). Neurite outgrowth on MAG was significantly increased when neurons were treated with putrescine, and this growth was unaffected by treatment with DRB, which confirmed that the effects of putrescine are not dependent on transcription (Fig. 5D). Conversely, when neurons were treated with a combination of putrescine and cycloheximide, the effects of putrescine were abolished, and neurite outgrowth in the presence of MAG was significantly reduced (Fig. 5D). Based on these findings and those of the preceding experiments, we propose that polyamines overcome inhibition by MAG by inducing expression of $\mathrm{p} 35$, and that this response is regulated at the translational level.

\section{Polyamine-induced expression of p35 is dependent on the hypusination of eIF5A}

In mammalian cells, mRNA translation is initiated by eukaryotic initiation factors, and there is a unique connection between polyamines and eIF5A, which is the only protein known to undergo hypusination. This irreversible posttranslational modification is produced by deoxyhypusine synthase (DHS)-mediated transfer of the 4-aminobutyl group of spermidine to the $\varepsilon$-amino group of Lys50 on eIF5A (Park, 2006). This generates deoxyhypusine, which is then hydroxylated by deoxyhypusine hydroxylase to form hypusine (Park, 2006). Hypusination is essential for eIF5A function, as mutation of the hypusine residue abolishes the ability of eIF5A to interact with the ribosome (Jao and Chen, 2006). Interestingly, our laboratory has shown that putrescine must be converted to spermidine to overcome inhibition by MAG and promote axonal regeneration in vivo (Deng et al., 2009), and we have therefore hypothesized that hypusination of eIF5A is required for polyamine-induced expression of $\mathrm{p} 35$ and the ability of polyamines to overcome inhibition by MAG.

To test this hypothesis, hypusination of eIF5A was blocked by inhibiting DHS activity, and this was accomplished using two different approaches: treatment with GC-7, a pharmacological inhibitor of DHS, and siRNA knockdown of DHS. In these experiments, p35 levels were significantly increased in CGNs treated with putrescine (Fig. 6A), but in the presence of either 1 or $10 \mu \mathrm{M}$ GC-7, putrescine-induced increases in $\mathrm{p} 35$ were blocked (Fig. 6A). Treatment with GC-7 also blocked the ability of putrescine to overcome MAG-mediated inhibition of neurite outgrowth in vitro (Fig. 6B). Similarly, a scrambled siRNA had no effect on putrescine-induced expression of p35 (Fig. 6C), but when DHS was knocked down, p35 expression was not induced in response to putrescine (Fig. $6 \mathrm{C}$ ). In our neurite outgrowth assays, neurons transfected with DHS siRNA and treated with putrescine were unable to overcome inhibition by MAG, and neurite outgrowth was significantly reduced compared to neurons treated with putrescine alone, or a combination of putrescine and scrambled siRNA (Fig. 6D). It should be noted that the effects of GC-7 and DHS siRNA were specific to p35, as these treatments had no effect on the expression of Cdk5 (Fig. 6A,C).

Last, we performed additional siRNA experiments to show that eIF5A is specifically required for polyamine-induced increases in p35 expression and the ability to overcome inhibition by MAG. CGNs were transfected with either eIF5A siRNA or scrambled siRNA and treated with $100 \mu \mathrm{M}$ putrescine for $24 \mathrm{~h}$. These neurons were then used for Western blotting to analyze eIF5A and p35 levels, and in neurite outgrowth assays. In neurons treated with either putrescine alone or putrescine and scrambled siRNA, we observed a significant increases in p35 (Fig. 7A), and corresponding significant increases in neurite outgrowth when these neurons were plated on MAG substrates (Fig. 7B). When
eIF5A was knocked down, however, putrescine failed to induce p35 expression (Fig. 7A), and its ability to promote neurite outgrowth on MAG was abolished (Fig. $7 B$ ). To provide further evidence of eIF5A's involvement in this process, we performed gain of function experiments in which the siRNA-knockdown of eIF5A was rescued by ectopic expression of eIF5A. DRG neurons were transfected with either scrambled siRNA or siRNA targeting the 3'UTR of eIF5A, and this was followed by transfection with an ORF clone expressing eGFP-tagged human eIF5A. Transfected neurons were then treated with $100 \mu \mathrm{M}$ putrescine for $24 \mathrm{~h}$ and used for neurite outgrowth assays. Neurons treated with putrescine were able to overcome inhibition by MAG, and this effect was sustained in the presence of the scrambled siRNA (Fig. 7C). As in the previous experiment, neurons that received eIF5A siRNA were unable to overcome MAG-mediated inhibition when treated with putrescine (Fig. 7C). However, introduction of the eIF5A ORF clone restored putrescine-mediated neurite outgrowth on MAG in the presence of the eIF5A siRNA (Fig. 7C). This confirms that eIF5A is required to mediate the effects of putrescine, and collectively these results demonstrate that DHS-mediated hypusination of eIF5A underlies putrescine's ability to induce p35 expression and overcome inhibition by MAG.

\section{Discussion}

Based on the results obtained in this study, we propose the following mechanism for cAMP- and polyamine-induced neurite outgrowth and reversal of inhibition by CNS myelin. Elevation of intracellular cAMP leads to increased expression of arginase I and a corresponding increase in putrescine levels, which can also be accomplished through administration of exogenous putrescine. Putrescine is then rapidly converted to spermidine, which serves as a substrate for the hypusination of eIF5A within the neuron. The activated eIF5A will initiate translation of $\mathrm{p} 35$, which will then bind to and activate $\mathrm{Cdk} 5$, and $\mathrm{Cdk} 5$ will in turn stimulate enhanced neurite outgrowth in the presence of MAG and other myelin-associated inhibitors.

The elucidation of this mechanism raises interesting questions about how Cdk5 promotes axonal growth and the potential substrates that may be phosphorylated in response to Cdk5 activation. Proteins that are involved in cytoskeletal regulation are logical candidates for these roles, and Cdk5 phosphorylates many proteins that affect actin dynamics, such as WAVE (WiskottAldrich syndrome protein-family verprolin-homologous protein), CaMKII, Cables, amphiphysin, and synapsin I (Matsubara et al., 1996; Zukerberg et al., 2000; Floyd et al., 2001; Dhavan et al., 2002; Kim et al., 2006). Phosphorylation of these proteins by Cdk5 has been shown to have a variety of effects on neuronal morphology and function including induction of cortical neuritogenesis (Zukerberg et al., 2000; Floyd et al., 2001), sequestration of synaptic vesicles (Verstegen et al., 2014), and increased dendritic spine formation in hippocampal neurons (Kim et al., 2006). Cdk5 also regulates actin polymerization by modulating the activity of the Rho family of small GTPases. Cdk 5 can influence Rac signaling and cytoskeletal remodeling by phosphorylating the Rac effector p21-activated kinase 1 (Pak1; Nikolic et al., 1998; Rashid et al. 2001). This is accomplished through the formation of Rac-p35/Cdk5-Pak1 complexes within neuronal growth cones, which leads to the phosphorylation of Pak1 by Cdk5/p35 in a Rac-dependent manner (Nikolic et al., 1998). To overcome inhibition by MAG and CNS myelin, however, the most likely target for Cdk5 would be RhoA, as MAG and Nogo have been shown to activate RhoA and its downstream effector 
A
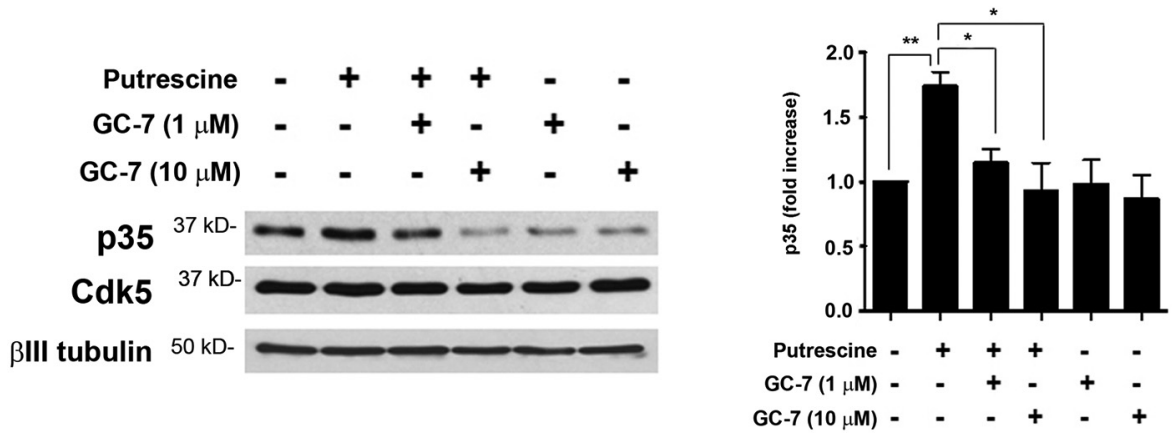

B

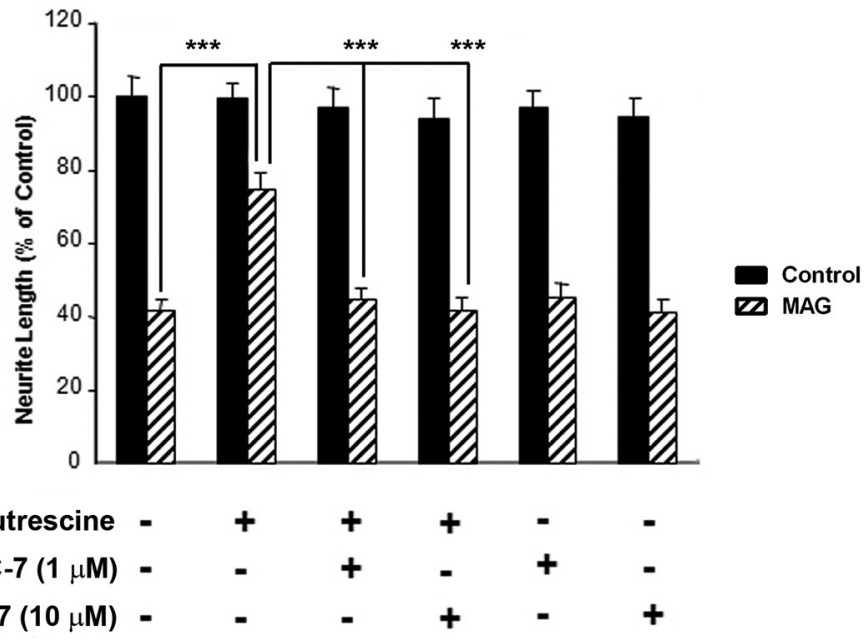

C

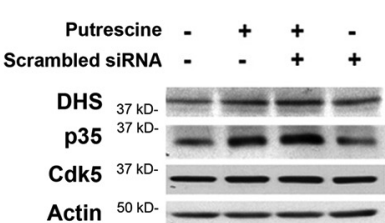

$\begin{array}{rlll}\text { Putrescine } & - & + & + \\ \text { DHS siRNA } & - & - & +\end{array}$

DHS $37 \mathrm{kD}$ -

p35 ${ }^{37 \mathrm{kD}-}$

Cdk5 ${ }^{37 \mathrm{kD}-}$

Actin $50 \mathrm{kD}$
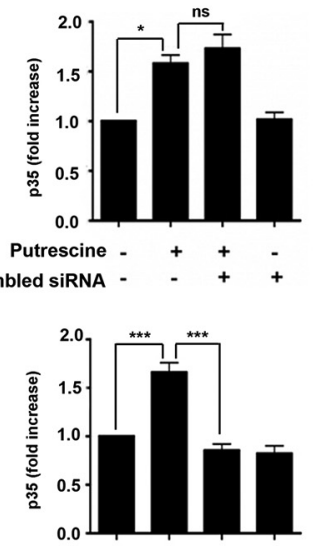

Putrescine - +++

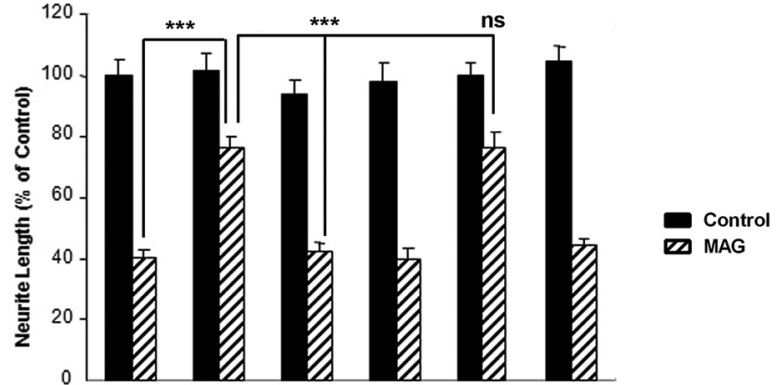

$\begin{array}{rllllll}\text { Putrescine } & - & + & + & - & + & - \\ \text { DHS siRNA } & - & - & + & + & - & - \\ \text { Dbled siRNA } & - & - & - & - & + & +\end{array}$

Figure 6. Loss of DHS activity abolishes putrescine's ability to induce $\mathrm{p} 35$ expression and overcome inhibition by MAG. $\boldsymbol{A}$, Western blots of CGNs treated with $100 \mu \mathrm{m}$ putrescine and 1 or $10 \mu \mathrm{M}$ GC-7 for $20 \mathrm{~h}(n=3)$. The graph represents densitometric measurements that have been normalized to the control (untreated neurons) and depicted as average fold changes \pm SEM. $\boldsymbol{B}$, Quantification of neurite outgrowth for CGNs primed with $100 \mu \mathrm{m}$ putrescine and 1 or $10 \mu \mathrm{m} \mathrm{GC-7}$ and plated on monolayers of control or MAG-expressing CH0 cells. C, Western blots of CGNs treated with $100 \mu \mathrm{m}$ putrescine and $300 \mathrm{~nm}$ scrambled siRNA for $20 \mathrm{~h}(n=3)$, and CGNs treated with $100 \mu \mathrm{m}$ putrescine and $300 \mathrm{~nm}$ DHS siRNA for $20 \mathrm{~h}(n=3)$. Graphs represent densitometric measurements that have been normalized to the control (untreated neurons) and depicted as average fold changes \pm SEM. D, Quantification of neurite outgrowth for (GNs treated with $100 \mu \mathrm{M}$ putrescine and $300 \mathrm{~nm}$ DHS or scrambled siRNA and plated on monolayers of control or MAG-expressing CH0 cells. For all experiments, neurite outgrowth was measured from a minimum of 200 neurons for each treatment. Graphs represent the average length of the longest neurite per neuron (depicted as percentage of control) \pm SEM. ${ }^{*} p<0.05$; ${ }^{* *} p<0.01 ;{ }^{* *} p<0.001$. ns, Not significant.

Rho kinase (Yamashita et al., 2002; Alabed et al., 2006). Blocking RhoA activity has also been shown to promote axonal regeneration in the presence of myelin-associated inhibitors (Lehmann et al., 1999; Fournier et al., 2003). At present, there is little informa- tion on how Cdk5 affects RhoA signaling in neurons, but in a previous cancer study, Cdk5 was shown to negatively regulate Rho activity in non-small cell lung cancer cells by phosphorylating the Rho-GTPase activating protein (Rho-GAP) DLC1 (Tri- 
A

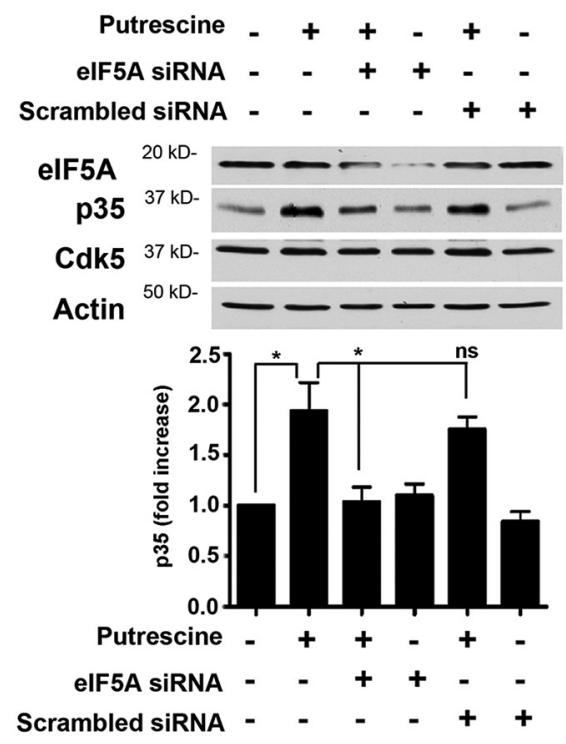

B

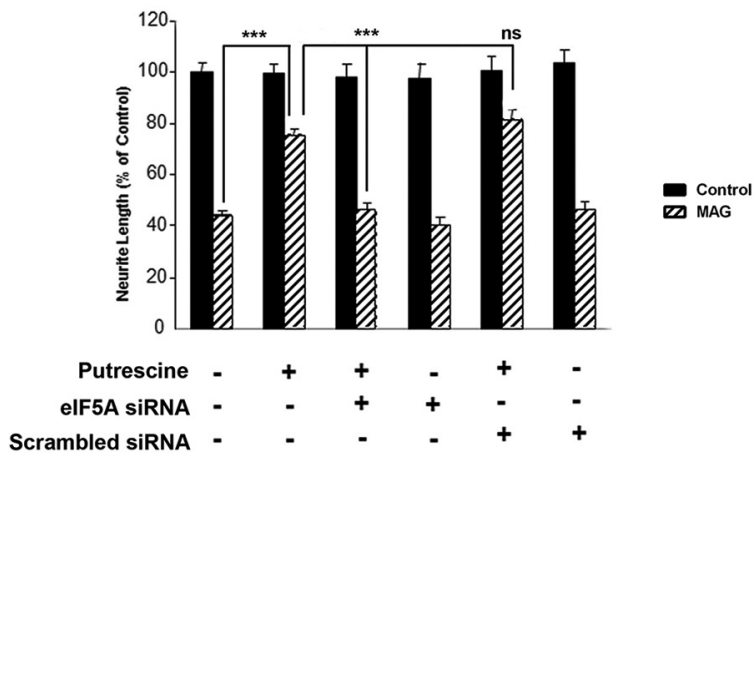

C

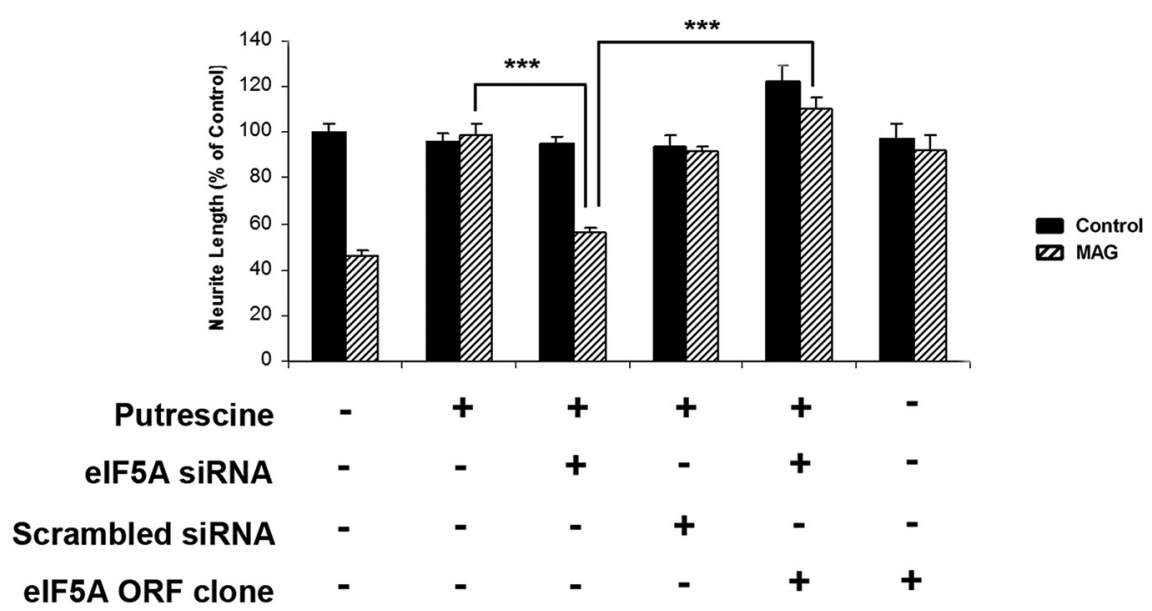

Figure 7. elF5A is required for putrescine-mediated expression of $\mathrm{p} 35$ and reversal of inhibition by MAG. $A$, Western blots of GGN treated with $100 \mu \mathrm{M}$ putrescine and $300 \mathrm{~nm}$ elF5A or scrambled siRNA for $20 \mathrm{~h}(n=3)$. Graphs represent densitometric measurements that have been normalized to the control (untreated neurons) and depicted as average fold changes \pm SEM. ${ }^{*} p<0.05 . \boldsymbol{B}$, Quantification of neurite outgrowth for CGNs treated with $100 \mu \mathrm{m}$ putrescine and $300 \mathrm{~nm}$ elF5A or scrambled siRNA and plated on monolayers of control or MAG-expressing CHO cells. C, Quantification of neurite outgrowth for DRG neurons treated with $100 \mu \mathrm{m}$ putrescine, elF5A or scrambled siRNA, and an elF5A ORF clone and plated on monolayers of control or MAG-expressing CHO cells. For all experiments, neurite outgrowth was measured from a minimum of 200 neurons for each treatment. Graphs represent the average length of the longest neurite per neuron (depicted as percentage of control) \pm SEM. ${ }^{* * *} p<0.001$. ns, Not significant.

pathi et al. 2014). It is therefore possible that Cdk5 may inhibit RhoA activity within neurons by activating Rho-GAPs, which would counteract myelin-induced activation of RhoA and facilitate neurite extension.

Microtubule dynamics are similarly influenced by Cdk5, which is abundant in microtubule preparations isolated from bovine brain (Ishiguro et al., 1992; Sobue et al., 2000). Phosphorylation of focal adhesion kinase by Cdk5 plays a critical role in microtubule organization and neuronal migration (Xie et al., 2003), and several microtubule-associated proteins (MAPs) including MAP2, MAP1B, and tau are substrates of Cdk5 (Paglini and Cáceres, 2001). Hyperphosphorylation of tau by Cdk5 prevents tau from associating with microtubules (Patrick et al., 1999), and this leads to tau aggregation and the formation of the neurofibrillary tangles that are hallmarks of Alzheimer's disease
(Noble et al., 2003). However, it should be noted that this pathological response only occurs when Cdk5 binds to p25, a truncated form of $\mathrm{p} 35$ produced by calpain-mediated cleavage of the full-length protein (Patrick et al., 1999). Conversely, phosphorylation of MAP1B by $\mathrm{p} 35 / \mathrm{Cdk} 5$ has been linked to laminininduced neurite extension in cerebellar neurons (Pigino et al., 1997; Paglini et al., 1998), netrin 1-mediated axonal guidance in the developing forebrain and hippocampus (Del Río et al., 2004), and the growth and stabilization of embryonic retinal ganglion cell axons (Hahn et al., 2005). Interestingly, in preliminary experiments conducted by our laboratory, we observed that treatment with putrescine led to increased phosphorylation of MAP1B, but not tau, in CGNs, and this response could be blocked by roscovitine (data not shown). This suggests that $\mathrm{Cdk} 5$ can differentially phosphorylate its substrates to exert its effects and that Cdk5- 
dependent phosphorylation of MAP1B could underlie the ability of putrescine to overcome inhibition by CNS myelin.

Whereas the substrates and functions of Cdk 5 in the CNS have been well characterized, the same cannot be said for eIF5A. There is little information available regarding eIF5A's function in neurons, as the vast majority of eIF5A studies have focused on its role in regulating cell survival and proliferation in both yeast and mammalian cells (Zanelli and Valentini, 2007), but there is some evidence that eIF5A is required for neurite outgrowth from PC12 cells and hippocampal neurons (Huang et al., 2007). However, virtually nothing is known about the proteins that are translated in response to eIF5A activation. In this study we show that hypusination of eIF5A leads to increased translation of $\mathrm{p} 35$, which results in Cdk5 activation and reversal of myelin-mediated inhibition. To the best of our knowledge, this is the first time that a neuron-specific protein has been identified as a product of eIF5A-mediated translation, and we also believe that this is the first report to describe functional outcomes that can be directly attributed to eIF5A activity in neurons. In our immunocytochemistry experiments, eIF5A was observed throughout the cell bodies and processes of CGNs (data not shown), and in response to putrescine treatment, we observed a dramatic upregulation of p35 that was concentrated in the neurites and growth cones of CGNs (Fig. 4). This raises the possibility that eIF5A is initiating local translation of $\mathrm{p} 35$ within the growth cones, and this is supported by a study reporting that eIF5A is enriched in the dendritic processes of Purkinje cells, where it is well established that local protein synthesis occurs (Luchessi et al., 2008). Although eIF5A has classically been defined as a translation initiation factor (Benne and Hershey, 1978; Smit-McBride et al., 1989), it was shown previously that eIF5A can act as an elongation and termination factor as well (Saini et al., 2009), and the fact that eIF5A can independently execute all three phases of translation strongly suggests that the p35 expressed in response to putrescine was produced through local translation mediated by eIF5A.

In addition to providing greater insight into the basic mechanisms that govern eIF5A and Cdk5 activity, our findings also have implications for the development of strategies to overcome inhibition by myelin and promote axonal regeneration after CNS injury. One potential target is $\mathrm{p} 35$, as we have shown that overexpression of $\mathrm{p} 35$ is sufficient to overcome inhibition by MAG in vitro. There are several factors that must be taken into account, however, before a similar approach could be considered for use in translational studies. The first is that viral overexpression of p35 would likely not be a viable approach for clinical applications, from both a technical and safety standpoint, and so alternative means of inducing p35 expression would be required. These could include gene-based therapies or, most logically, exogenous administration of spermidine, which has been shown previously to promote axonal regeneration in the optic nerve (Deng et al., 2009). Importantly, spermidine has been shown to cross the blood-brain barrier following cerebral ischemia (Diler et al., 2002), and so it is possible that entry of spermidine into the CNS would be facilitated after traumatic injury. A second factor to consider is that elevated expression of p35 could be accompanied by higher levels of p25, which, as mentioned, has been conclusively linked to neurodegeneration (Patrick et al., 1999). It would therefore be prudent to monitor p25 levels in future studies involving induction of $\mathrm{p} 35$ expression.

In addition to p35, identification of the substrates and signaling pathways activated by $\mathrm{Cdk} 5$ could also prove to be a valuable source of new targets for therapeutic intervention, and it would be particularly interesting to test whether these targets could work synergistically with other proregenerative agents that we have identified, such as interleukin-6 (Cao et al. 2006), secretory leukocyte protease inhibitor (Hannila et al., 2013), and metallothioinein I/II (Siddiq et al., 2015) to enhance axonal regeneration. Our findings also have broader implications for the study of the nervous system, as the mechanisms described in this study advance our understanding of the functions of eIF5A and Cdk5 in neurons and provide a basis for further studies examining how these proteins affect fundamental processes such as synaptogenesis, differentiation, and neuronal survival.

\section{References}

Alabed YZ, Grados-Munro E, Ferraro GB, Hsieh SH, Fournier AE (2006) Neuronal responses to myelin are mediated by rho kinase. J Neurochem 96:1616-1625. CrossRef Medline

Benne R, Hershey JW (1978) The mechanism of action of protein synthesis initiation factors from rabbit reticulocytes. J Biol Chem 253:3078-3087. Medline

Bibb JA, Chen J, Taylor JR, Svenningsson P, Nishi A, Snyder GL, Yan Z, Sagawa ZK, Ouimet CC, Nairn AC, Nestler EJ, Greengard P (2001) Effects of chronic exposure to cocaine are regulated by the neuronal protein Cdk5. Nature 410:376-380. CrossRef Medline

Cai D, Shen Y, De Bellard M, Tang S, Filbin MT (1999) Prior exposure to neurotrophins blocks inhibition of axonal regeneration by MAG and myelin via a cAMP-dependent mechanism. Neuron 22:89-101. CrossRef Medline

Cai D, Deng K, Mellado W, Lee J, Ratan RR, Filbin MT (2002) Arginase I and polyamines act downstream from cyclic AMP in overcoming inhibition of axonal growth MAG and myelin in vitro. Neuron 35:711-719. CrossRef Medline

Cao Z, Gao Y, Bryson JB, Hou J, Chaudhry N, Siddiq M, Martinez J, Spencer T, Carmel J, Hart RB, Filbin MT (2006) The cytokine interleukin-6 is sufficient but not necessary to mimic the peripheral conditioning lesion effect on axonal growth. J Neurosci 26:5565-5573. CrossRef Medline

Del Río JA, González-Billault C, Ureña JM, Jiménez EM, Barallobre MJ, Pascual M, Pujadas L, Simó S, La Torre A, Wandosell F, Avila J, Soriano E (2004) MAP1B is required for Netrin 1 signaling in neuronal migration and axonal guidance. Curr Biol 2004 May 25;14(10):840-850.

Deng K, He H, Qiu J, Lorber B, Bryson JB, Filbin MT (2009) Increased synthesis of spermidine as a result of upregulation of arginase I promotes axonal regeneration in culture and in vivo. J Neurosci 29:9545-9552. CrossRef Medline

Dhavan R, Tsai LH (2001) A decade of CDK5. Nat Rev Mol Cell Biol 2:749759. CrossRef Medline

Dhavan R, Greer PL, Morabito MA, Orlando LR, Tsai LH (2002) The cyclin-dependent kinase 5 activators p 35 and p39 interact with the alphasubunit of $\mathrm{Ca} 2+/$ calmodulin-dependent protein kinase II and alphaactinin-1 in a calcium dependent manner. J Neurosci 22:7879-7891. Medline

Diler AS, Ziylan YZ, Uzum G, Lefauconnier JM, Seylaz J, Pinard E (2002) Passage of spermidine across the blood-brain barrier in short recirculation periods following global cerebral ischemia: effects of mild hyperthermia. Neurosci Res 43:335-342. CrossRef Medline

Filbin MT (2003) Myelin-associated inhibitors of axonal regeneration in the adult mammalian CNS. Nat Rev Neurosci 4:703-713. CrossRef Medline

Floyd SR, Porro EB, Slepnev VI, Ochoa GC, Tsai LH, De Camilli P (2001) Amphiphysin 1 binds the cyclin-dependent kinase (cdk) 5 regulatory subunit p35 and is phosphorylated by cdk5 and cdc2. J Biol Chem 276: 8104-8110. CrossRef Medline

Fournier AE, Takizawa BT, Strittmatter SM (2003) Rho kinase inhibition enhances axonal regeneration in the injured CNS. J Neurosci 23: 1416-1423. Medline

Gutierrez E, Shin BS, Woolstenhulme CJ, Kim JR, Saini P, Buskirk AR, Dever TE (2013) eIF5A promotes translation of polyproline motifs. Mol Cell 51:35-45. CrossRef Medline

Hahn CM, Kleinholz H, Koester MP, Grieser S, Thelen K, Pollerberg GE (2005) Role of cyclin-dependent kinase 5 and its activator P35 in local axon and growth cone stabilization. Neuroscience 134:449-465. CrossRef Medline

Hannila SS, Siddiq MM, Carmel JB, Hou J, Chaudhry N, Bradley PM, Hilaire M, Richman EL, Hart RP, Filbin MT (2013) Secretory leukocyte pro- 
tease inhibitor reverses inhibition by CNS myelin, promotes regeneration in the optic nerve, and suppresses expression of the TGF $\beta$ signaling protein Smad2. J Neurosci 33:5138-5151. CrossRef Medline

Harada T, Morooka T, Ogawa S, Nishida E (2001) ERK induces p35, a neuron-specific activator of Cdk5, through induction of Egr1. Nat Cell Biol 3:453-459. CrossRef Medline

Huang Y, Higginson DS, Hester L, Park MH, Snyder SH (2007) Neuronal growth and survival mediated by eIF5A, a polyamine-modified translation initiation factor. Proc Natl Acad Sci U S A 104:4194-4199. CrossRef Medline

Ishiguro K, Takamatsu M, Tomizawa K, Omori A, Takahashi M, Arioka M, Uchida T, Imahori K (1992) Tau protein kinase I converts normal tau protein into A68-like component of paired helical filaments. J Biol Chem 267:10897-10901. Medline

Jao DL, Chen KY (2006) Tandem affinity purification revealed the hypusine-dependent binding of eukaryotic initiation factor $5 \mathrm{~A}$ to the translating 80S ribosomal complex. J Cell Biochem 97:583-598. CrossRef Medline

Johansson JU, Lilja L, Chen XL, Higashida H, Meister B, Noda M, Zhong ZG, Yokoyama S, Berggren PO, Bark C (2005) Cyclin-dependent kinase 5 activators p35 and p39 facilitate formation of functional synapses. Brain Res Mol Brain Res 138:215-227. CrossRef Medline

Kim Y, Sung JY, Ceglia I, Lee KW, Ahn JH, Halford JM, Kim AM, Kwak SP, Park JB, Ho Ryu S, Schenck A, Bardoni B, Scott JD, Nairn AC, Greengard P (2006) Phosphorylation of WAVE1 regulates actin polymerization and dendritic spine morphology. Nature 442:814-817. CrossRef Medline

Lehmann M, Fournier A, Selles-Navarro I, Dergham P, Sebok A, Leclerc N, Tigyi G, McKerracher L (1999) Inactivation of Rho signaling pathway promotes CNS axon regeneration. J Neurosci 19:7537-7547. Medline

Lew J, Huang QQ, Qi Z, Winkfein RJ, Aebersold R, Hunt T, Wang JH (1994) A brain-specific activator of cyclin-dependent kinase 5. Nature 371: 423-426. CrossRef Medline

Luchessi AD, Cambiaghi TD, Alves AS, Parreiras-E-Silva LT, Britto LR, Costa-Neto CM, Curi R (2008) Insights on eukaryotic translation initiation factor 5A (eIF5A) in the brain and aging. Brain Res 1228:6-13. CrossRef Medline

Matsubara M, Kusubata M, Ishiguro K, Uchida T, Titani K, Taniguchi H (1996) Site specific phosphorylation of synapsin I by mitogen-activated protein kinase and Cdk5 and its effects on physiological functions. J Biol Chem 271:21108-21113. CrossRef Medline

Nikolic M, Dudek H, Kwon YT, Ramos YF, Tsai LH (1996) The cdk5/p35 kinase is essential for neurite outgrowth during neuronal differentiation. Genes Dev 10:816-825. CrossRef Medline

Nikolic M, Chou MM, Lu W, Mayer BJ, Tsai LH (1998) The p35/Cdk5 kinase is a neuron-specific Rac effector that inhibits Pak1 activity. Nature 395:194-198. CrossRef Medline

Noble W, Olm V, Takata K, Casey E, Mary O, Meyerson J, Gaynor K, LaFrancois J, Wang L, Kondo T, Davies P, Burns M, Veeranna, Nixon R, Dickson D, Matsuoka Y, Ahlijanian M, Lau LF, Duff K (2003) Cdk5 is a key factor in tau aggregation and tangle formation in vivo. Neuron 38:555-565. CrossRef Medline

Norton WT, Poduslo SE (1973) Myelination in rat brain: method of myelin isolation. J Neurochem 21:749-757. CrossRef Medline

Paglini G, Cáceres A (2001) The role of the Cdk5-p35 kinase in neuronal development. Eur J Biochem 268:1528-1533. Medline

Paglini G, Pigino G, Kunda P, Morfini G, Maccioni R, Quiroga S, Ferreira A, Cáceres A (1998) Evidence for the participation of the neuron-specific CDK5 activator P35 during laminin-enhanced axonal growth. J Neurosci 18:9858-9869. Medline

Park MH (2006) The post-translational synthesis of a polyamine-derived amino acid, hypusine, in the eukaryotic translation initiation factor $5 \mathrm{~A}$ (eIF5A). J Biochem 139:161-169. CrossRef Medline

Patrick GN, Zukerberg L, Nikolic M, de la Monte S, Dikkes P, Tsai LH (1999) Conversion of p 35 to p 25 deregulates Cdk 5 activity and promotes neurodegeneration. Nature 402:615-622. CrossRef Medline

Pigino G, Paglini G, Ulloa L, Avila J, Cáceres A (1997) Analysis of the expression, distribution and function of cyclin dependent kinase 5 (cdk5) in developing cerebellar macroneurons. J Cell Sci 110:257-270. Medline

Qiu J, Cai D, Dai H, McAtee M, Hoffman PN, Bregman BS, Filbin MT (2002) Spinal axon regeneration induced by elevation of cyclic AMP. Neuron 34:895-903. CrossRef Medline

Rashid T, Banerjee M, Nikolic M (2001) Phosphorylation of Pak1 by the p35/Cdk5 kinase affects neuronal morphology. J Biol Chem 276:4904349052. CrossRef Medline

Saini P, Eyler DE, Green R, Dever TE (2009) Hypusine-containing protein eIF5A promotes translation elongation. Nature 459:118-121. CrossRef Medline

Siddiq MM, Hannila SS, Carmel JB, Bryson JB, Hou J, Nikulina E, Willis MR, Mellado W, Richman EL, Hilaire M, Hart RP, Filbin MT (2015) Metallothionein-I/II promotes axonal regeneration in the central nervous system. J Biol Chem 290:16343-16356. CrossRef Medline

Smit-McBride Z, Dever TE, Hershey JW, Merrick WC (1989) Sequence determination and cDNA cloning of eukaryotic initiation factor $4 \mathrm{D}$, the hypusine-containing protein. J Biol Chem 264:1578-1583. Medline

Sobue K, Agarwal-Mawal A, Li W, Sun W, Miura Y, Paudel HK (2000) Interaction of neuronal $\mathrm{Cdc} 2$-like protein kinase with microtubuleassociated protein tau. J Biol Chem 275:16673-16680. CrossRef Medline

Tang D, Yeung J, Lee KY, Matsushita M, Matsui H, Tomizawa K, Hatase O, Wang JH (1995) An isoform of the neuronal cyclin-dependent kinase 5 (Cdk5) activator. J Biol Chem 270:26897-26903. CrossRef Medline

Tripathi BK, Qian X, Mertins P, Wang D, Papageorge AG, Carr SA, Lowy DR (2014) CDK5 is a major regulator of the tumor suppressor DLC1. J Cell Biol 207:627-642. CrossRef Medline

Tsai LH, Takahashi T, Caviness VS Jr, Harlow E (1993) Activity and expression pattern of cyclin-dependent kinase 5 in the embryonic mouse nervous system. Development 119:1029-1040. Medline

Tsai LH, Delalle I, Caviness VS Jr, Chae T, Harlow E (1994) p35 is a neuralspecific regulatory subunit of cyclin-dependent kinase 5. Nature 371: 419-423. CrossRef Medline

Verstegen AM, Tagliatti E, Lignani G, Marte A, Stolero T, Atias M, Corradi A, Valtorta F, Gitler D, Onofri F, Fassio A, Benfenati F (2014) Phosphorylation of synapsin I by cyclin-dependent kinase- 5 sets the ratio between the resting and recycling pools of synaptic vesicles at hippocampal synapses. J Neurosci 34:7266-7280. CrossRef Medline

Xie Z, Sanada K, Samuels BA, Shih H, Tsai LH (2003) Serine 732 phosphorylation of FAK by Cdk5 is important for microtubule organization, nuclear movement, and neuronal migration. Cell 114:469-482. CrossRef Medline

Yamashita T, Higuchi H, Tohyama M (2002) The p75 receptor transduces the signal from myelin-associated glycoprotein to Rho. J Cell Biol 157: 565-570. CrossRef Medline

Zanelli CF, Valentini SR (2007) Is there a role for eIF5A in translation? Amino Acids 33:351-358. CrossRef Medline

Zhao CT, Li K, Li JT, Zheng W, Liang XJ, Geng AQ, Li N, Yuan XB (2009) PKCdelta regulates cortical radial migration by stabilizing the Cdk5 activator p35. Proc Natl Acad Sci U S A 106:21353-21358. CrossRef Medline

Zukerberg LR, Patrick GN, Nikolic M, Humbert S, Wu CL, Lanier LM, Gertler FB, Vidal M, Van Etten RA, Tsai LH (2000) Cables links Cdk5 and c-Abl and facilitates Cdk5 tyrosine phosphorylation, kinase upregulation, and neurite outgrowth. Neuron 26:633-646. CrossRef Medline 